ANL-6665

Metals, Ceramics, and Materials (TID-4500, 24th Ed.) .

AEC Research and Development Report

ARGONNE NATIONAL LABORATORY

9700 South Cass Avenue

Argonne, Illinois 60440

\title{
IRRADIATION AND POSTIRRADIATION ANNEALING OF SOME ALUMINUM-BASE FUELS
}

by

C. F. Reinke

Final Report - Metallurgy Program 6.1.35

A portion of the material contained in this report has been reported in the following Metallurgy Division Reports:

$\begin{array}{ccc}\text { Report No. } & \text { Pages } & \text { Date } \\ \text { ANL-5975 } & 20 & 1958 \\ \text { ANL-6516 } & 141-142 & \text { December 1961 } \\ \text { ANL-6677 } & 122-123 & \text { December } 1962\end{array}$

September 1963

Operated by The University of Chicago

under

Contract W-31-109-eng-38.

with the

U. S. Atomic Energy Commission 


\section{DISCLAIMER}

This report was prepared as an account of work sponsored by an agency of the United States Government. Neither the United States Government nor any agency Thereof, nor any of their employees, makes any warranty, express or implied, or assumes any legal liability or responsibility for the accuracy, completeness, or usefulness of any information, apparatus, product, or process disclosed, or represents that its use would not infringe privately owned rights. Reference herein to any specific commercial product, process, or service by trade name, trademark, manufacturer, or otherwise does not necessarily constitute or imply its endorsement, recommendation, or favoring by the United States Government or any agency thereof. The views and opinions of authors expressed herein do not necessarily state or reflect those of the United States Government or any agency thereof. 


\section{DISCLAIMER}

Portions of this document may be illegible in electronic image products. Images are produced from the best available original document. 


\section{TABLE OF CONTENTS}

Page

ABSTRACT .

INTRODUCTION. . . . . . . . . . . . . . . . . . . . . 7

FABRICATION HISTORY . . . . . . . . . . . . . . . . . . . 8

EXPERIMENTAL PROCEDURE . . . . . . . . . . . . . . . 9

I. Irradiation Experiments ................. 9

II. Annealing Studies................... 10

EXPERIMENTAL RESULTS AND DISCUSSION. . . . . . . . . . 13

I. Aluminum-39 w/o $\mathrm{U}_{3} \mathrm{O}_{8}$ Dispersion ............ 13

A. Postirradiation Examination. ........... 13

B. Postirradiation Annealing ............ 21

C. $\mathrm{U}_{3} \mathrm{O}_{8}$-Aluminum Reaction............. 23

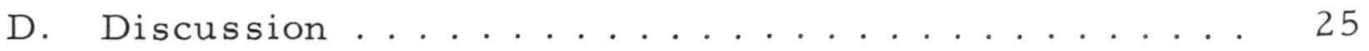

II. Aluminum-17.3 w/o Uranium Alloy ............ 25

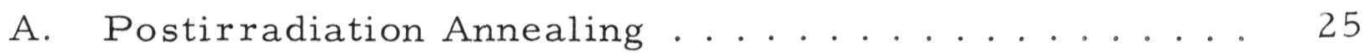

B. Metallographic Examination........... 28

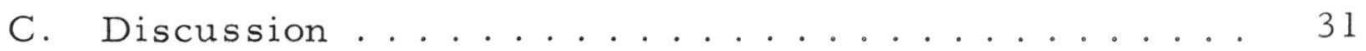

III. General Comparison between the Alloy and Dispersion

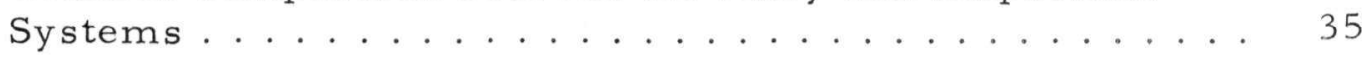

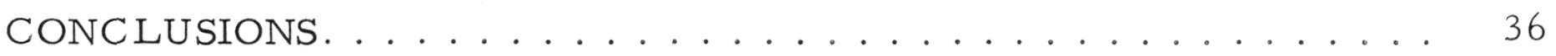

ACKNOW LEDGEMENTS . . . . . . . . . . . . . . . . . . . . 36

REFERENCES . . . . . . . . . . . . . . . . . . . 37

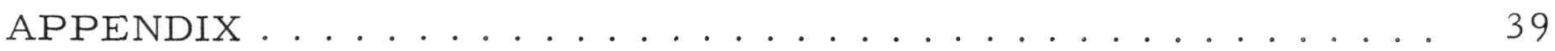




\section{LIST OF FIGURES}

No. Title

Page

1. Typical Dispersion Specimen Used in the Annealing Studies. .

2. Schematic Drawing of Assembled Irradiation Capsule . . . . 10

3. Effective Specimen Flux for Position MTR A-1-NW ..... 10

4. Typical Alloy Specimens Used in the Annealing Studies..... 11

5. Aluminum-39 w/o $\mathrm{U}_{3} \mathrm{O}_{8}$ Dispersion Specimens Used in the

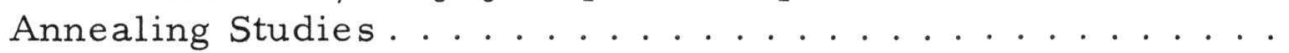

6. As-irradiated Condition of Specimens ED-1 through ED-9...

7. As-fabricated Structure of $\mathrm{U}_{3} \mathrm{O}_{8}$-Aluminum Dispersion Specimens. . . . . . . . . . . . . . . . .

8. Specimen ED-1 after Irradiation to $0.20 \times 10^{20} \mathrm{Fissions} / \mathrm{cc}$ Burnup at $55^{\circ} \mathrm{C} \ldots \ldots \ldots \ldots \ldots$

9. Specimen ED-7 after Irradiation to $0.88 \times 10^{20}$ Fissions/cc Burnup at $85^{\circ} \mathrm{C} \ldots \ldots \ldots \ldots \ldots$

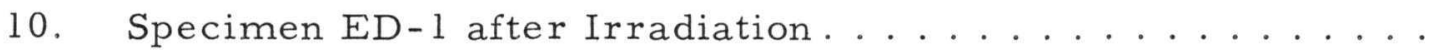

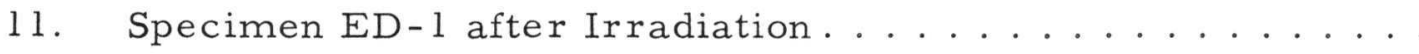

12. Specimen ED-1 after Irradiation. . . . . . . . . . . 20

13. Specimen ED-7 after Irradiation. . . . . . . . . . 20

14. Specimen ED-7 after Irradiation. ............. 20

15. Specimen ED-6 at Conclusion of Annealing Study . ...... 22

16. Severe Blistering on Specimen W-12-TE ........ 27

17. Blistering on Specimen W-12-TES. ........... 27

18. Growth of Fuel Core out of Cladding on Specimen W-12-6... 27

19. Specimen W-12-6 Showing Particles of $\mathrm{UAl}_{4}$ in Aluminum-

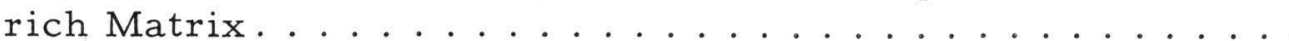




\section{LIST OF FIGURES}

No.

Title

$\underline{\text { Page }}$

20. Specimen W-12-6 Showing Particles of $\mathrm{UAl}_{4}$ in Aluminum-

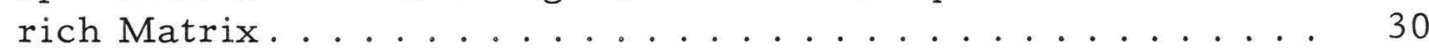

21. $\mathrm{UAl}_{4}$ Particles in Aluminum Matrix of Specimen W-12-TES . 31

22. Void Formation in Specimen W-12-TES ......... 31

23. Specimen W-12-TES Showing Void Formation along Line

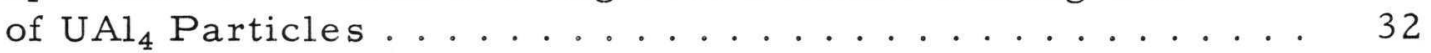

24. Aluminum-Uranium Phase Diagram............ 33

25. Swelling in Aluminum-17 to $20 \mathrm{w} / \mathrm{o}$ Uranium Alloy Specimens as a Function of Burnup and Temperature........ 


\section{LIST OF TABLES}

No.

Title

Page

I. Chemical and Isotopic Analyses of $\mathrm{U}_{3} \mathrm{O}_{8}-$ Aluminum Dis persion Specimens................... 8

II. Irradiation History of $\mathrm{U}_{3} \mathrm{O}_{8}$ Dispersion Specimens . . . . . 10

III. Comparison of Pre- and Postirradiation Density Measure-

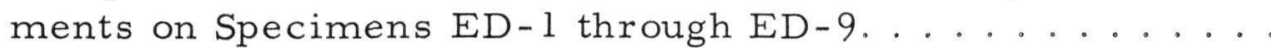

IV. Comparison of Pre- and Postirradiation Dimensional Measurements on Specimens ED-1 through ED-9.......

V. Comparison of Pre- and Postirradiation Weights of Speci-

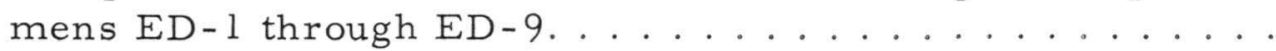

VI. Annealing History of Irradiated $39 \mathrm{w} / 0 \mathrm{U}_{3} \mathrm{O}_{8}$-Aluminum

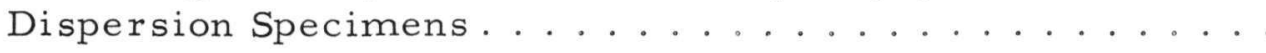

VII. Annealing History of Unirradiated $39 \mathrm{w} / \mathrm{o} \mathrm{U}_{3} \mathrm{O}_{8}-$ Aluminum

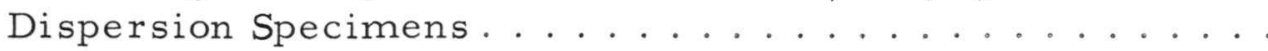

VIII. X-ray Diffraction Analyses of Unirradiated $\mathrm{U}_{3} \mathrm{O}_{8}$-Aluminum

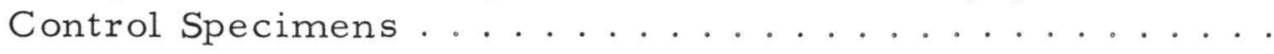

IX. Annealing History of Irradiated Aluminum-17.3 w/o Ura-

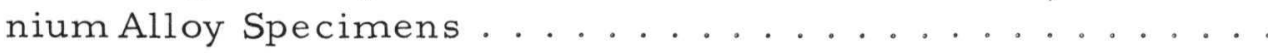

X. Annealing History of Unirradiated Aluminum-17.3 w/o Uranium Alloy Specimens . . . . . . . . . . . . . 
○ 


\title{
IRRADIATION AND POSTIRRADIATION ANNEALING OF SOME ALUMINUM-BASE FUELS
}

by

C. F. Reinke

\begin{abstract}
Irradiated specimens of $39 \mathrm{w} / 0 \quad \mathrm{U}_{3} \mathrm{O}_{8}$ dispersed in aluminum and of aluminum-17.3 w/o uranium alloy were annealed. Each specimen was partially clad with aluminum.

Gross swelling was not observed for the aluminum$39 \mathrm{w} / 0 \mathrm{U}_{3} \mathrm{O}_{8}$ dispersion specimens for burnup and annealing temperature levels ranging up to $1.0 \times 10^{20}$ fissions per cc and $550^{\circ} \mathrm{C}$, respectively. Small volume increases were found, however, and these were attributed to the aluminum reduction of $\mathrm{U}_{3} \mathrm{O}_{8}$, which is accompanied by measurable volume increases. X-ray diffraction analyses confirmed the reaction between the $\mathrm{U}_{3} \mathrm{O}_{8}$ and the aluminum matrix. The dispersion specimens and, in particular, the $\mathrm{U}_{3} \mathrm{O}_{8}$ particles sintered during irradiation at temperatures from 55 to $90^{\circ} \mathrm{C}$ in an effective thermal-neutron flux of between 1 and $3 \times 10^{13} \mathrm{nv}$.

Annealing at $550^{\circ} \mathrm{C}$ produced severe localized blistering on specimens of aluminum $-17.3 \mathrm{w} / \mathrm{o} \mathrm{uranium}$ alloy having burnups of $5.9 \times 10^{20}$ fissions per cc. Similar conditions produced only a small uniform volume increase when the burnup was $1.4 \times 10^{20}$ fissions per cc. The observed stability is attributed to a defect structure in the compound $\mathrm{UAl}_{4}$ in which unoccupied uranium sites trap fission products and, in particular, fission product gases.
\end{abstract}

\section{INTRODUCTION}

One of the most important characteristics of a reactor fuel material is dimensional stability during irradiation. Metallic and cermet fuels if heated during or after irradiation reach a temperature at which large volume increases of the unrestrained solid materials occur in a relatively short time, i.e., they reach the swelling temperature. Therefore, operation at or above this temperature is not feasible without restraint. The useful operating temperature can be extended by suitable cladding or jacketing of the fuel core; but there are practical limitations on the amount of 
restraint that can be incorporated into the design of a fuel element. Thus, a knowledge of the swelling temperature of a fuel is essential in defining its operating limitations. To obtain this information for two aluminumbase fuels, a series of annealing studies were made with irradiated aluminum-39 w/o $\mathrm{U}_{3} \mathrm{O}_{8}$ dispersion specimens and with irradiated aluminum$17.3 \mathrm{w} / \mathrm{o}$ uranium alloy.

\section{FABRICATION HISTORY}

The $\mathrm{U}_{3} \mathrm{O}_{8}$ - aluminum dispersion specimens were made as thin strips by hot extruding a powder mixture consisting of $39 \mathrm{w} / \mathrm{o}$ of $\mathrm{U}_{3} \mathrm{O}_{8}$ in aluminum. (1,2) This type of fuel has been used in the Argonaut Reactor. (3) Prior to mixing with the aluminum powder, the $\mathrm{U}_{3} \mathrm{O}_{8}$ was calcined overnight at $1000^{\circ} \mathrm{C}$ in air and ground to minus 100 mesh. The aluminum and $\mathrm{U}_{3} \mathrm{O}_{8}$ powders were then mixed and ball milled overnight to assure proper blending, after which they were loaded into an aluminum can. Prior to extrusion, the billets were heated to $480^{\circ} \mathrm{C}$ and held at that temperature for 12 to $14 \mathrm{hr}$. The extruded specimens had a thin aluminum cladding which varied from sample to sample and ranged from practically no cladding to about 0.006 in. maximum. The cut edges of the samples were left unclad. Chemical and isotopic analyses were made of the blended powders and finished specimens. The results are tabulated in Table I.

Table I

CHEMICAL AND ISOTOPIC ANALYSES OF $\mathrm{U}_{3} \mathrm{O}_{8}$-ALUMINUM DISPERSION SPECIMENS

\begin{tabular}{|c|c|c|c|c|c|c|}
\hline \multirow{2}{*}{ Specimen } & \multicolumn{5}{|c|}{ Powder Core, $\%$} & \multirow{2}{*}{$\begin{array}{c}\text { Extruded } \\
\text { Specimen, } \\
\% \mathrm{U}\end{array}$} \\
\hline & U & $\mathrm{U}^{234}$ & $\mathrm{U}^{235}$ & $U^{236}$ & $U^{238}$ & \\
\hline $\begin{array}{c}E D-1 \\
\text { to } \\
E D-3\end{array}$ & $33.7 \pm 0.7$ & $0.130 \pm 0.002$ & $19.1 \pm 0.2$ & $0.126 \pm 0.002$ & $80.6 \pm 0.2$ & $30.58 \pm 0.09$ \\
\hline $\begin{array}{c}E D-4 \\
\text { to } \\
E D-6\end{array}$ & $33.4 \pm 0.7$ & $0.127 \pm 0.003$ & $19.0 \pm 0.3$ & $0.124 \pm 0.003$ & $80.7 \pm 0.3$ & $29.44 \pm 0.06$ \\
\hline $\begin{array}{l}E D-7 \\
\text { to } \\
E D-9\end{array}$ & $33.4 \pm 0.7$ & $0.127 \pm 0.003$ & $19.0 \pm 0.3$ & $0.124 \pm 0.003$ & $80.7 \pm 0.3$ & $29.32 \pm 0.06$ \\
\hline
\end{tabular}

The $17.3 \mathrm{w} / \mathrm{o}$ uranium-aluminum alloy specimens were cut from a plate which had been irradiated in the ANL-2 loop in the MTR. (4) The plate was manufactured by the same procedures and with the same materials used in the manufacture of the SL-1 core.(5-7) The fuel core consisting of 2S aluminum with alloying additions in the following nominal amounts: $17.5 \mathrm{w} / \mathrm{o}$ uranium, $2.0 \mathrm{w} / \mathrm{o}$ nickel, and $0.5 \mathrm{w} / \mathrm{o}$ iron, was vacuum melted and cast into a graphite mold. The casting was conditioned, hot rolled at 
$580^{\circ} \mathrm{C}$, and then cold rolled to final size. The cladding material was M-388 aluminum alloy, which consists of $2 \mathrm{~S}$ aluminum with an addition of $1 \%$ of nickel. The core and cladding components were assembled in a "picture frame" and bonded by the silicon bonding technique. ( 8 ) The bonded assembly was reduced to finish thickness by hot rolling at $550^{\circ} \mathrm{C}$, followed by a cold sizing pass.

\section{EXPERIMENT AL PROCEDURE}

\section{Irradiation Experiments}

Figure 1 illustrates the geometry of the $\mathrm{U}_{3} \mathrm{O}_{8}$ dispersion specimens used in the studies. The dispersion specimens were encapsulated with NaK in capsules similar to the one shown in Figure 2. Each capsule contained one sample. The capsules were irradiated in MTR position A-1-NW from December 7, 1957 to July 7, 1958 for a total of 156.4 days at full power. Figure 3 is a plot of the location of each specimen versus the effective thermal-neutron flux in the position. The plot is based on $\mathrm{Cs}^{137}$ burnup analyses of specimens ED-1, ED-2, and ED-7 together with flux-monitor data which were obtained from each capsule. The data do not provide an indication of maximum or minimum flux values during irradiation; thus the flux listed is an average value throughout the period. Table II lists the irradiation history for each specimen based on the average flux values given in Figure 3. The irradiation temperatures were taken from a plot of the calculated central specimen temperature versus the power density, which was based on an electrical-geometrical analogue study of the capsule configuration.

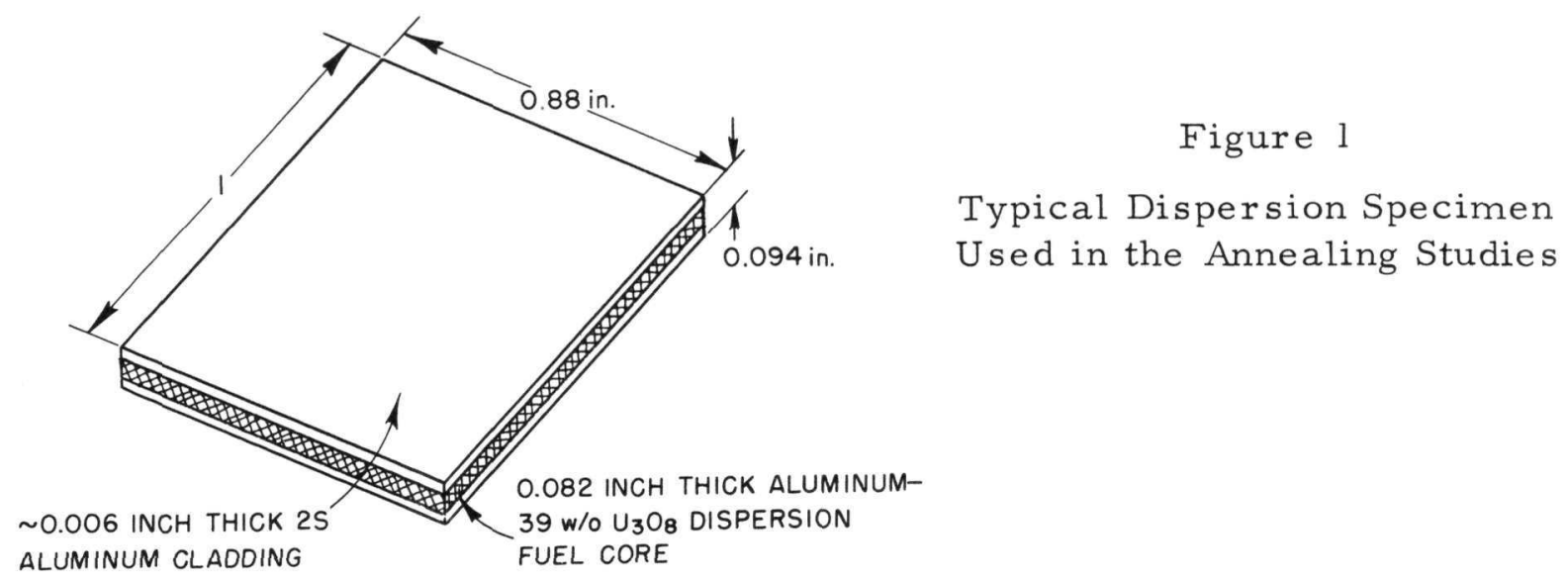

$106-7094$

The irradiation history of the $17.3 \mathrm{w} / \mathrm{o}$ uranium-aluminum alloy specimens is given in detail in Reference 4. In general, the plate from which the specimens were obtained was irradiated in the ANL-2 Argonne High Pressure Water Loop in the MTR for 125 full-power days and achieved a maximum total atom burnup of 1.0 percent as determined by radiochemical burnup analyses. 


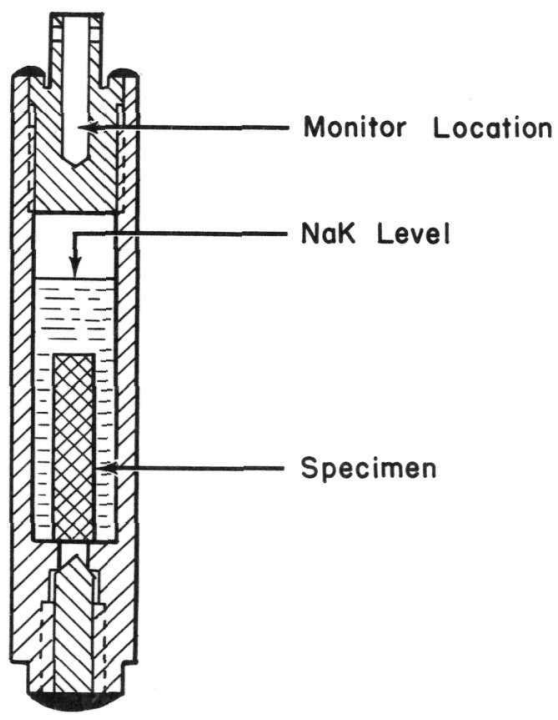

106-1760

Figure 2. Schematic Drawing of Assembled Irradiation Capsule. The drawing is not to scale.

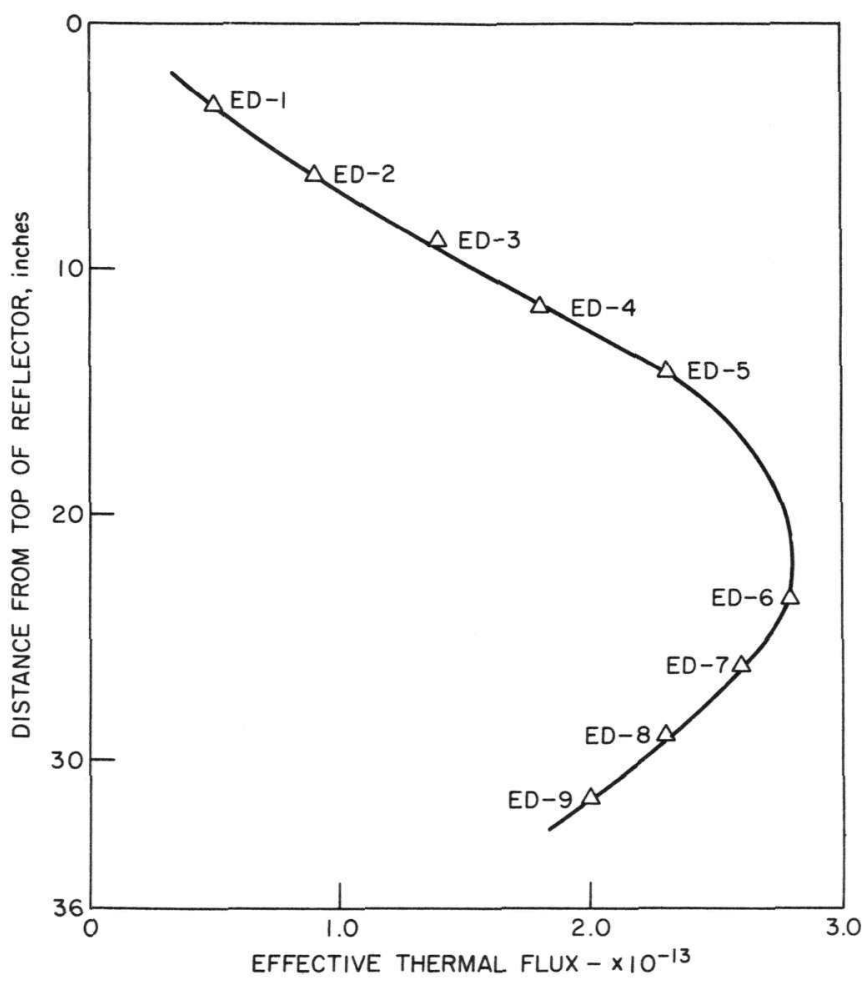

106-7095

Figure 3. Effective Specimen Flux for Position MTR A-1-NW

Table II

IRRADIATION HISTORY OF $\mathrm{U}_{3} \mathrm{O}_{8}$ DISPERSION SPECIMENS

\begin{tabular}{|c|c|c|c|c|}
\hline \multirow{2}{*}{ Capsule } & \multirow{2}{*}{$\begin{array}{c}\text { Specimen } \\
\text { No. }\end{array}$} & \multirow{2}{*}{$\begin{array}{c}\text { Central } \\
\text { Irradiation } \\
\text { Temp, }{ }^{\circ} \mathrm{C}\end{array}$} & \multicolumn{2}{|r|}{ Burnup } \\
\hline & & & $\mathrm{a} / \mathrm{o} \mathrm{U}^{235}$ & $(\mathrm{fiss} / \mathrm{cc}) \times 10^{-20}$ \\
\hline ANL-6-89 & ED - 1 & 55 & 4.0 & 0.20 \\
\hline ANL-6-90 & ED-2 & 60 & 6.9 & 0.36 \\
\hline ANL-6-91 & ED-3 & 70 & 10.5 & 0.54 \\
\hline ANL-6-92 & ED-4 & 75 & 13.2 & 0.64 \\
\hline ANL-6-93 & ED- 5 & 80 & 16.5 & 0.81 \\
\hline ANL-6-94 & ED-6 & 90 & 19.6 & 0.95 \\
\hline ANL-6-95 & ED-7 & 85 & 18.4 & 0.88 \\
\hline ANL-6-96 & ED- 8 & 80 & 16.5 & 0.80 \\
\hline ANL-6-97 & ED-9 & 75 & 14.6 & 0.71 \\
\hline
\end{tabular}

II. Annealing Studies

Figure 4 illustrates the geometry of the alloy specimens used in the annealing studies. The dispersion specimens used in the annealing studies are shown in Figure 5. The studies were conducted in salt pots 
heated by electric-resistance furnaces which were controlled by thermocouples situated between the pot and the furnace. A thermocouple, located inside a well in each pot, recorded the temperature of the salt and thus that of the specimens. The maximum temperature variation observed during each anneal was $\pm 10^{\circ} \mathrm{C}$, and usually the temperature remained within $\pm 5^{\circ} \mathrm{C}$ of the desired value.

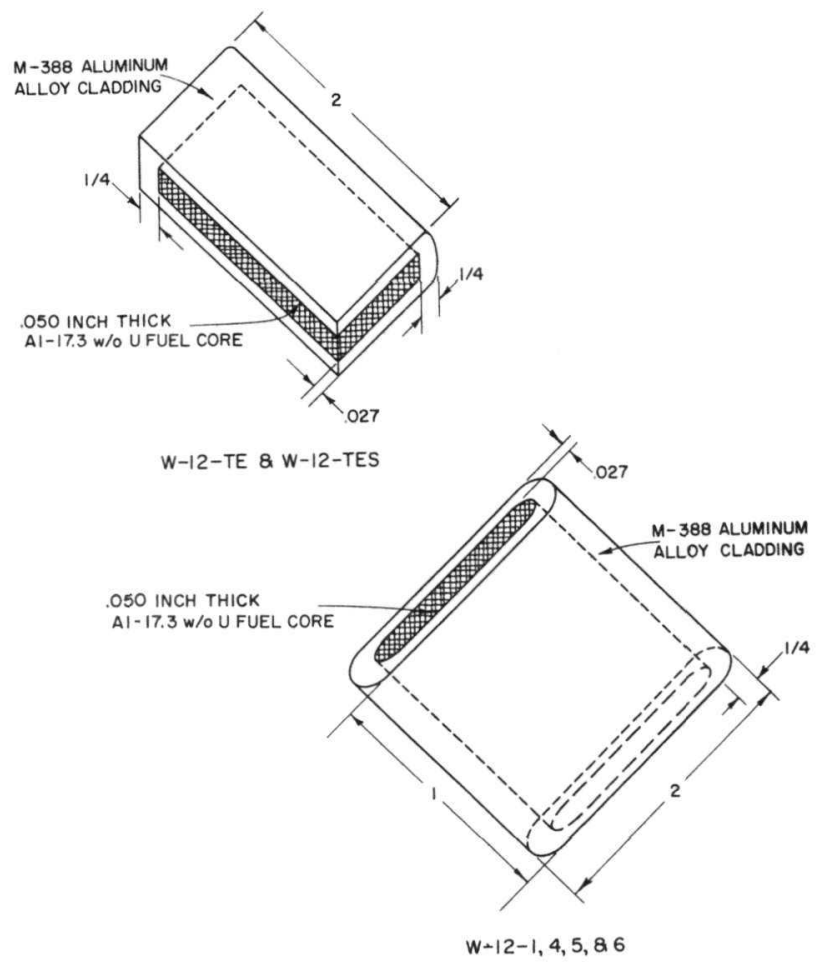

$106-7093$

Figure 4. Typical Alloy Specimens Used in the Annealing Studies

The specimens were placed, along with unirradiated control samples, in baskets which were lowered into the salt after it had stabilized at temperature. The salt provided a protective atmosphere during the annealing and minimized temperature gradients. At the completion of each annealing period the specimens were washed and rinsed in water, and dipped in acetone to facilitate drying. Dimensions and immersion densities were then taken and compared with the pre-test values to determine the magnitude of any changes.

The annealing studies at temperatures up to and including $365^{\circ} \mathrm{C}$ utilized a salt containing approximately 45 percent sodium nitrite $\left(\mathrm{NaNO}_{2}\right)$ and 55 percent potassium nitrate $\left(\mathrm{KNO}_{3}\right)$. The annealing studies at $500^{\circ} \mathrm{C}$ and $550^{\circ} \mathrm{C}$ utilized a salt containing equal parts of potassium and sodium nitrate. 
ED-6

0.95

90

24423

$2 \mathrm{X}$

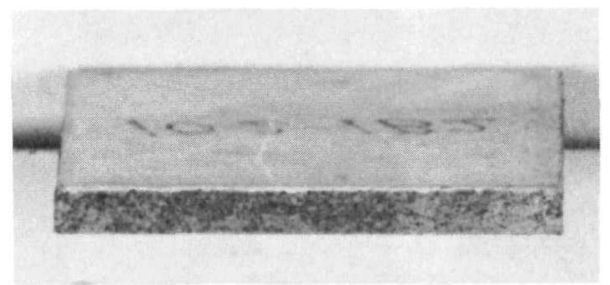

$$
\text { ED- } 8
$$

0.80

80

24425

$2 \mathrm{X}$

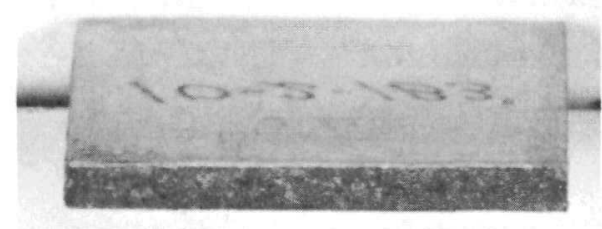

ED-9

0.71

75

24426

$2 \mathrm{X}$

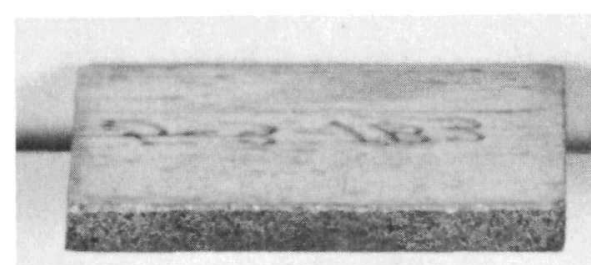

ED-3

0.54

70

24420

Figure 5. Aluminum-39 w/o $\mathrm{U}_{3} \mathrm{O}_{8}$ Dispersion Specimens Used in the Annealing Studies. Photos show unclad edge and numbered face of square specimens. 
I. Aluminum-39 w/o $\mathrm{U}_{3} \mathrm{O}_{8}$ Dispersion

\section{A. Postirradiation Examination}

The postirradiation examination revealed that the $\mathrm{U}_{3} \mathrm{O}_{8}$ dispersion specimens were in excellent condition. Figure 6 shows the specimens after irradiation. Their condition is not surprising as the irradiation temperatures and burnups were comparatively low. There is little doubt that the specimens would have operated satisfactorily at higher temperatures and burnup levels.

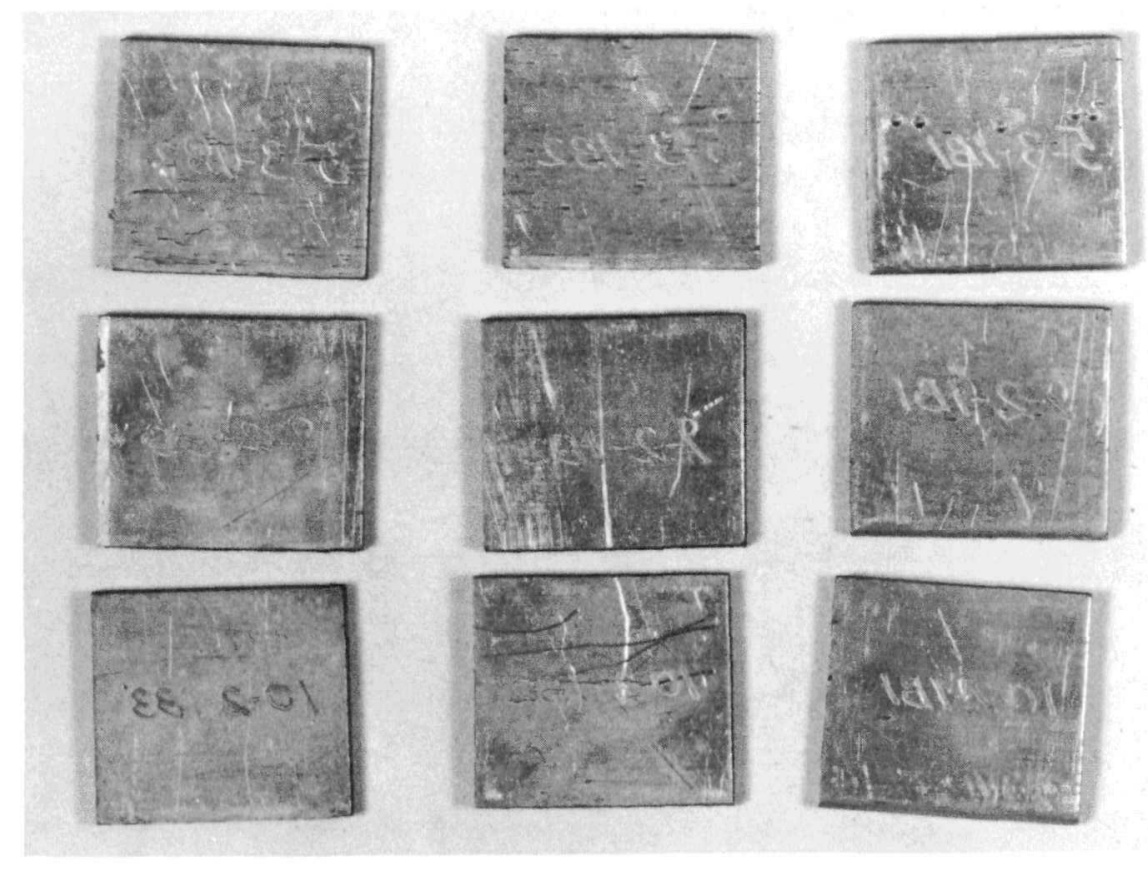

24417

IX

Figure 6. As-irradiated Condition of Specimens ED-1 through ED-9.

The observed changes in density and dimensions are presented in Tables III, IV, and V. With but one exception, ED-7, the samples densified under the conditions of irradiation. The reason for the anomalous value for ED-7 is not known; however, it is not believed to be a valid change. There was no correlation between these changes and either burnup or specimen irradiation temperature.

The length and width of each specimen remained constant while the thickness decreased. In all cases, although the changes were small and close to the precision of the measurements, the general trend for a decrease 
in thickness was well established. The dimensional data are difficult to interpret except in a general way because, due to their geometry, the specimens had a considerable range in values even before irradiation.

Table III

COMPARISON OF PRE- AND POSTIRRADIATION DENSITY MEASUREMENTS ON SPECIMENS ED-1 THROUGH ED-9

\begin{tabular}{|l|c|c|c|}
\hline \multirow{2}{*}{ Specimen } & \multicolumn{3}{|c|}{ Density, (a) g/cc } \\
\cline { 2 - 4 } & Pre & Post & $\% \Delta \rho$ \\
\hline ED-1 & 3.414 & 3.425 & +0.32 \\
ED-2 & 3.486 & 3.494 & +0.23 \\
ED-3 & 3.448 & 3.464 & +0.46 \\
ED-4 & 3.348 & 3.359 & +0.33 \\
ED-5 & 3.387 & 3.400 & +0.38 \\
ED-6 & 3.372 & 3.391 & +0.56 \\
ED-7 & 3.312 & 3.290 & -0.66 \\
ED-8 & 3.374 & 3.380 & +0.18 \\
ED-9 & 3.376 & 3.379 & +0.09 \\
\hline
\end{tabular}

(a) The estimated precision of the measurements is $\pm 0.004 \mathrm{~g} / \mathrm{cc}$ Table IV

COMPARISON OF PRE- AND POSTIRRADIATION DIMENSIONAL MEASUREMENTS ON SPECIMENS ED-1 THROUGH ED-9

\begin{tabular}{|c|c|c|c|}
\hline \multirow{2}{*}{ Specimen } & \multicolumn{3}{|c|}{ Dimensions, in. (a) } \\
\cline { 2 - 4 } & Length & Width & Thickness \\
\hline \multirow{2}{*}{ ED-1 } & Pre $1.002-1.003$ & 0.880 & $0.099-0.100$ \\
& Post $0.998-1.005$ & $0.880-0.882$ & $0.098-0.101$ \\
ED-2 & Pre $0.987-0.988$ & 0.883 & 0.101 \\
& Post $0.988-0.989$ & $0.882-0.883$ & $0.099-0.100$ \\
ED-3 & Pre $0.978-0.983$ & $0.884-0.885$ & 0.100 \\
ED-4 & Post $0.981-0.982$ & $0.884-0.885$ & 0.098 \\
& Pre $1.009-1.010$ & $0.884-0.885$ & $0.100-0.102$ \\
ED-6 & Post 1.008 & 0.884 & 0.099 \\
& Pre $1.014-1.023$ & 0.886 & $0.102-0.103$ \\
ED-7 & Post $1.016-1.021$ & $0.886-0.889$ & 0.100 \\
& Pre $1.022-1.034$ & $0.885-0.887$ & $0.100-0.101$ \\
ED-8 & Post $1.029-1.034$ & $0.888-0.889$ & 0.098 \\
& Pre $1.004-1.015$ & 0.881 & $0.099-0.100$ \\
ED-9 & Post $1.008-1.015$ & 0.882 & $0.097-0.098$ \\
& Pre $0.996-1.002$ & 0.884 & $0.101-0.102$ \\
& Post $1.001-1.003$ & $0.882-0.885$ & 0.100 \\
& Pre $0.984-0.990$ & $0.882-0.883$ & $0.099-0.100$ \\
& Post $0.988-0.990$ & 0.884 & $0.098-0.099$ \\
\hline
\end{tabular}

(a) The values represent a minimum of two readings for each dimension. Each individual value has a precision of \pm 0.001 in. 
Table V

COMPARISON OF PRE- AND POSTIRRADIATION WEIGHTS

OF SPECIMENS ED-1 THROUGH ED-9

\begin{tabular}{|l|c|c|c|}
\hline \multirow{2}{*}{ Specimen } & \multicolumn{3}{|c|}{ Weight, g } \\
\cline { 2 - 4 } & Pre & Post & Change \\
\hline ED-1 & 4.651 & 4.651 & - \\
ED-2 & 4.725 & 4.726 & +0.001 \\
ED-3 & 4.628 & 4.635 & +0.007 \\
ED-4 & 4.670 & 4.674 & +0.004 \\
ED-5 & 4.820 & 4.825 & +0.005 \\
ED-6 & 4.805 & 4.822 & +0.017 \\
ED-7 & 4.574 & 4.579 & +0.005 \\
ED-8 & 4.676 & 4.678 & +0.002 \\
ED-9 & 4.568 & 4.571 & +0.003 \\
\hline
\end{tabular}

The microstructure shown in Figure 7 is typical of the $\mathrm{U}_{3} \mathrm{O}_{8}$ dispersion specimens before irradiation. As can be seen, the larger particles of $\mathrm{U}_{3} \mathrm{O}_{8}$ were quite porous. There was no obvious evidence of any reaction between the $\mathrm{U}_{3} \mathrm{O}_{8}$ and the aluminum matrix. However, as seen in the photomicrograph at 750X, a careful examination at the higher magnification did reveal reaction zones surrounding some of the smaller particles. X-ray diffraction analyses confirmed the existence of these zones and indicated that approximately $10 \%$ of the oxide present was $\mathrm{UO}_{2}$. The $\mathrm{UO}_{2}$ probably formed prior to extrusion during the soaking period of 12 to $14 \mathrm{hr}$ at $480^{\circ} \mathrm{C}$ by aluminum reduction of the $\mathrm{U}_{3} \mathrm{O}_{8}$.

The increase in density, decrease in thickness, increase in weight, and postirradiation appearance of the $\mathrm{U}_{3} \mathrm{O}_{8}$ particles are all compatible with the hypothesis that sintering occurred during irradiation. Initially it was thought that $\mathrm{NaK}$ corrosion may have produced the observed densification; however, an attempt to explain the density, thickness, and weight data on the basis of NaK corrosion was not successful. Since the face of each specimen was clad with aluminum, a preferential removal of aluminum by NaK corrosion would have the effect of increasing the density of the composite specimen and decreasing the specimen thickness concurrently. The increase in weight would then be attributed to oxidized NaK coolant picked up by the exposed fuel at the edges of the specimen. The calculations were based on measured weights and densities, and indicated that if the observed decrease in thickness were attributed to aluminum corrosion, the increase in density of the composite, due to the loss of the lower-density aluminum cladding, still would not be equal to the observed densification. Furthermore, the surface appearance of the specimens, 
shown in Figure 6, and the low overall specimen irradiation temperature of approximately $100^{\circ} \mathrm{C}$ indicate that corrosion of the aluminum cladding was not a problem. Calculations indicate that the temperature drop within individual oxide particles is less than $10^{\circ} \mathrm{C}$. Thus, all the data indicate that sintering had indeed occurred even though the irradiation temperatures were approximately $100^{\circ} \mathrm{C}$.

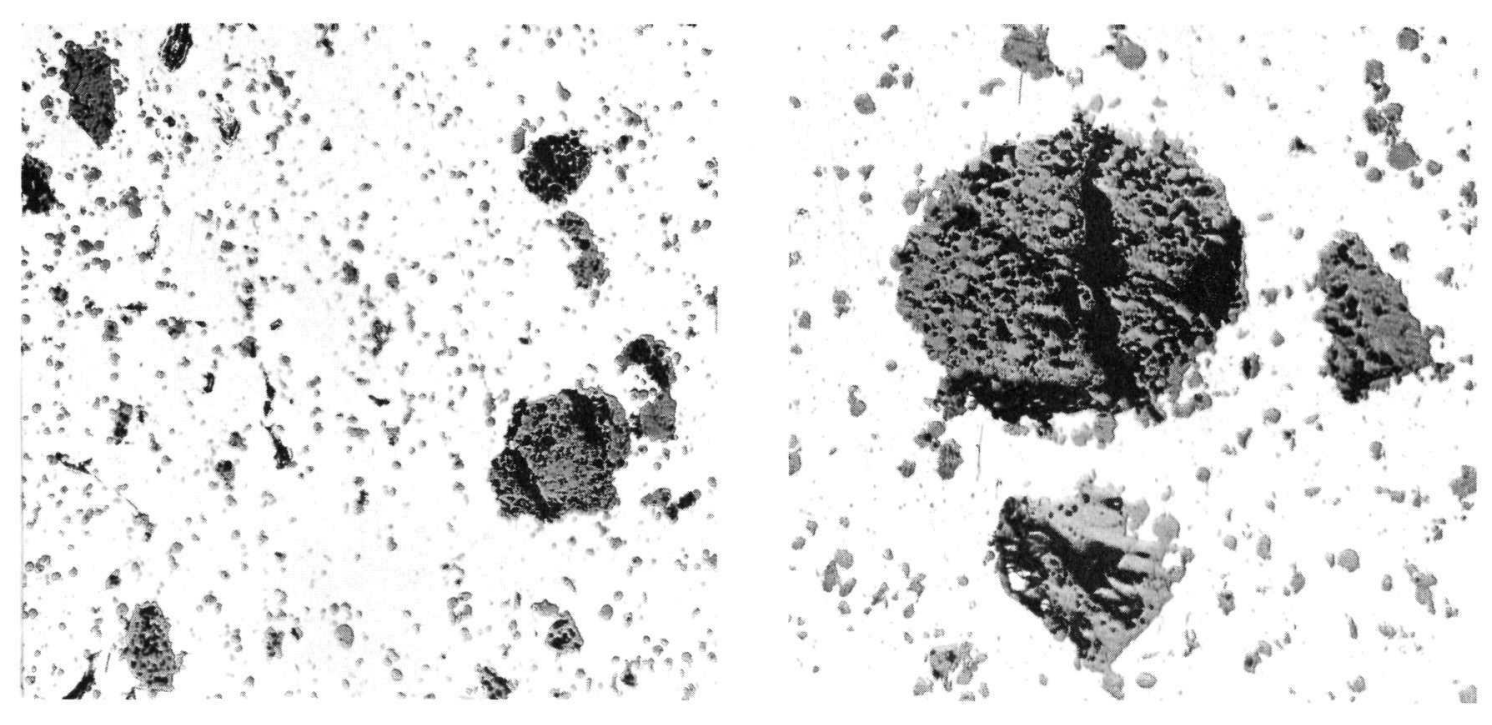

EI-573

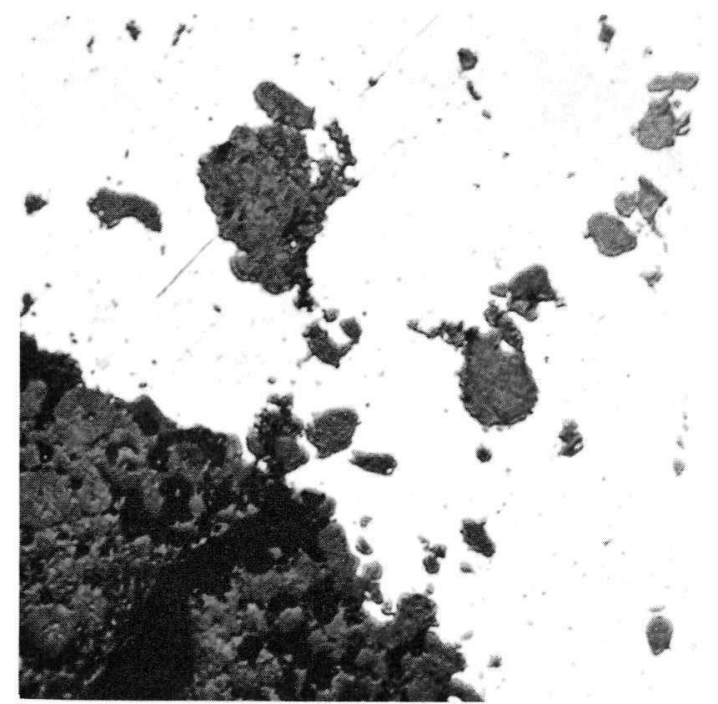

EI-576

$750 X$

Figure 7. As-fabricated Structure of $\mathrm{U}_{3} \mathrm{O}_{8}$-Aluminum Dispersion Specimens. The photos show the specimens in the as-polished condition.

Figures 8 through 14 are typical of the structure existing after irradiation. As can be seen, the $\mathrm{U}_{3} \mathrm{O}_{8}$ particles had undergone sintering even though the irradiation temperatures were estimated well below the 


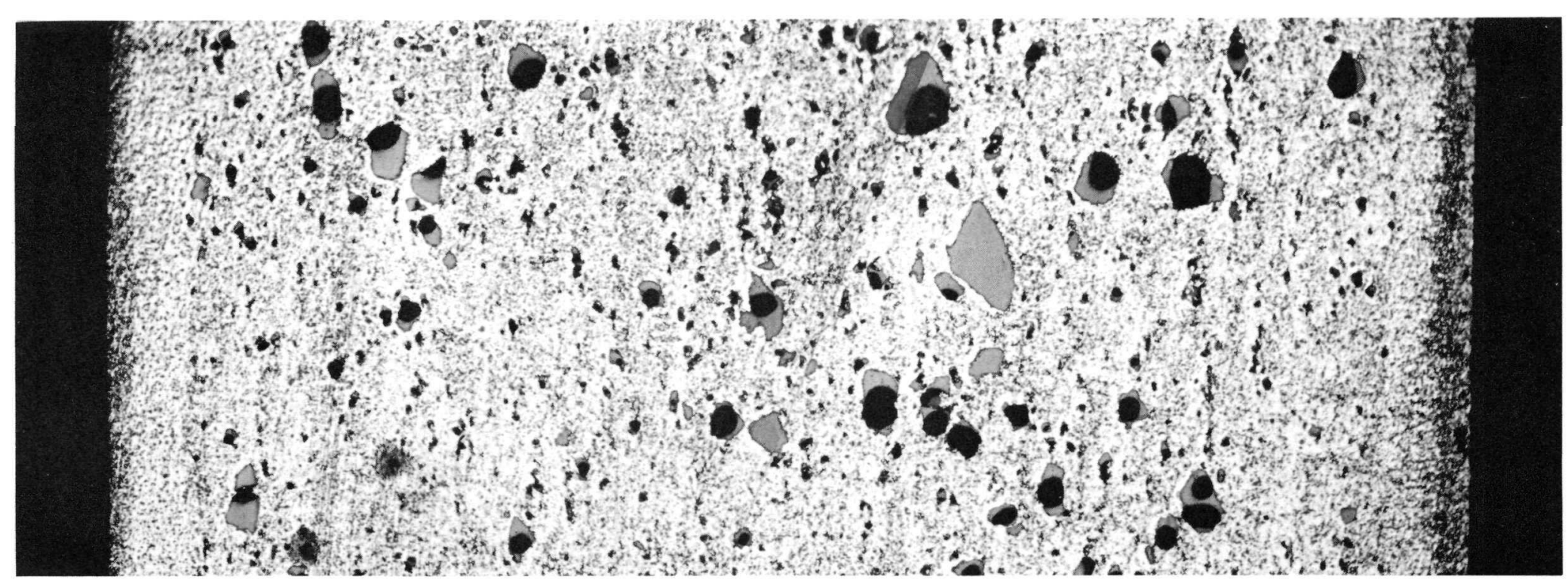

Figure 8. Specimen ED-1 after Irradiation to $0.20 \times 10^{20}$ Fissions/Cc Burnup at $55^{\circ} \mathrm{C}$. 


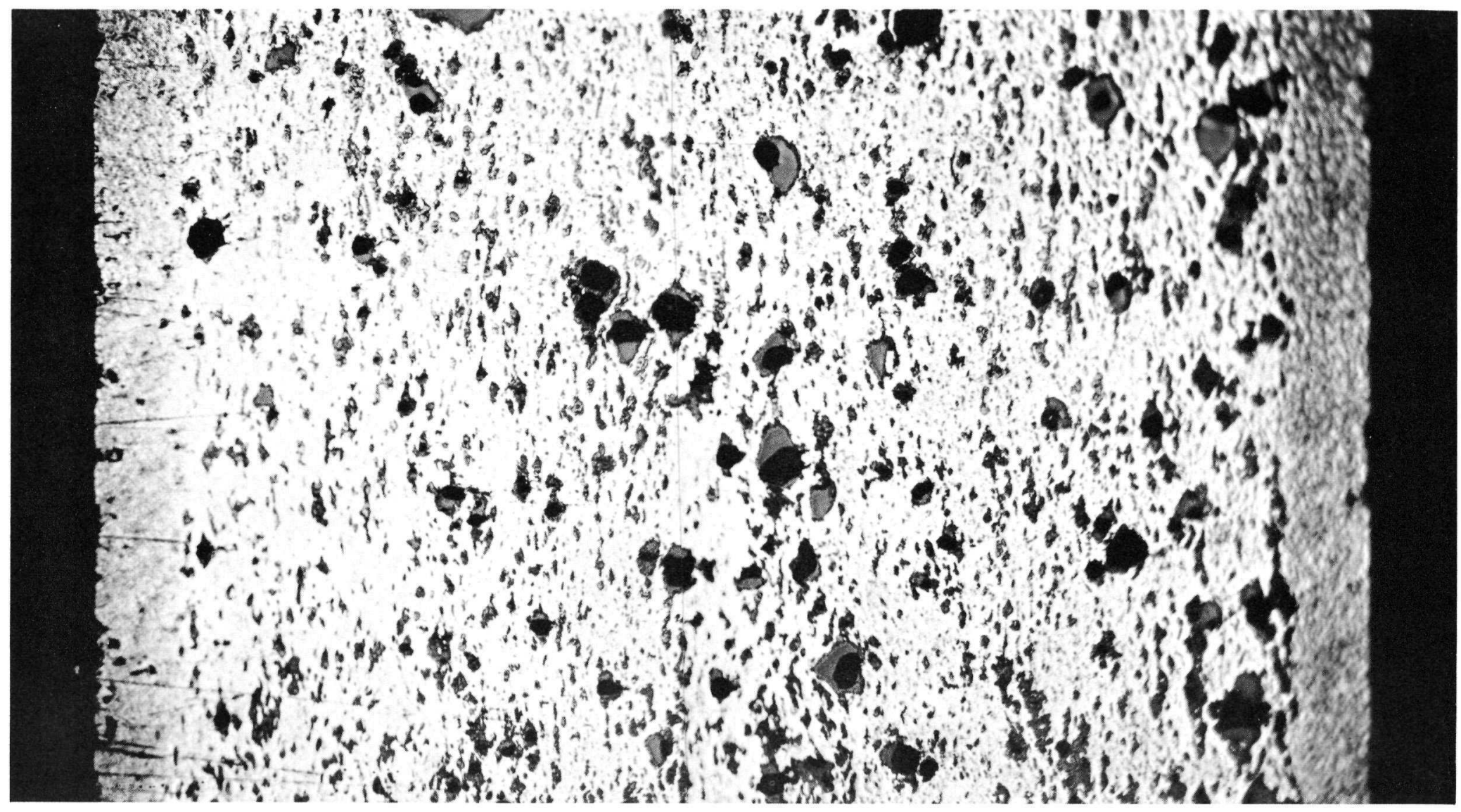

EI-863

Figure 9. Specimen ED-7 after Irradiation to $0.88 \times 10^{20} \mathrm{Fissions} / \mathrm{cC}$ Burnup at $85^{\circ} \mathrm{C}$. 


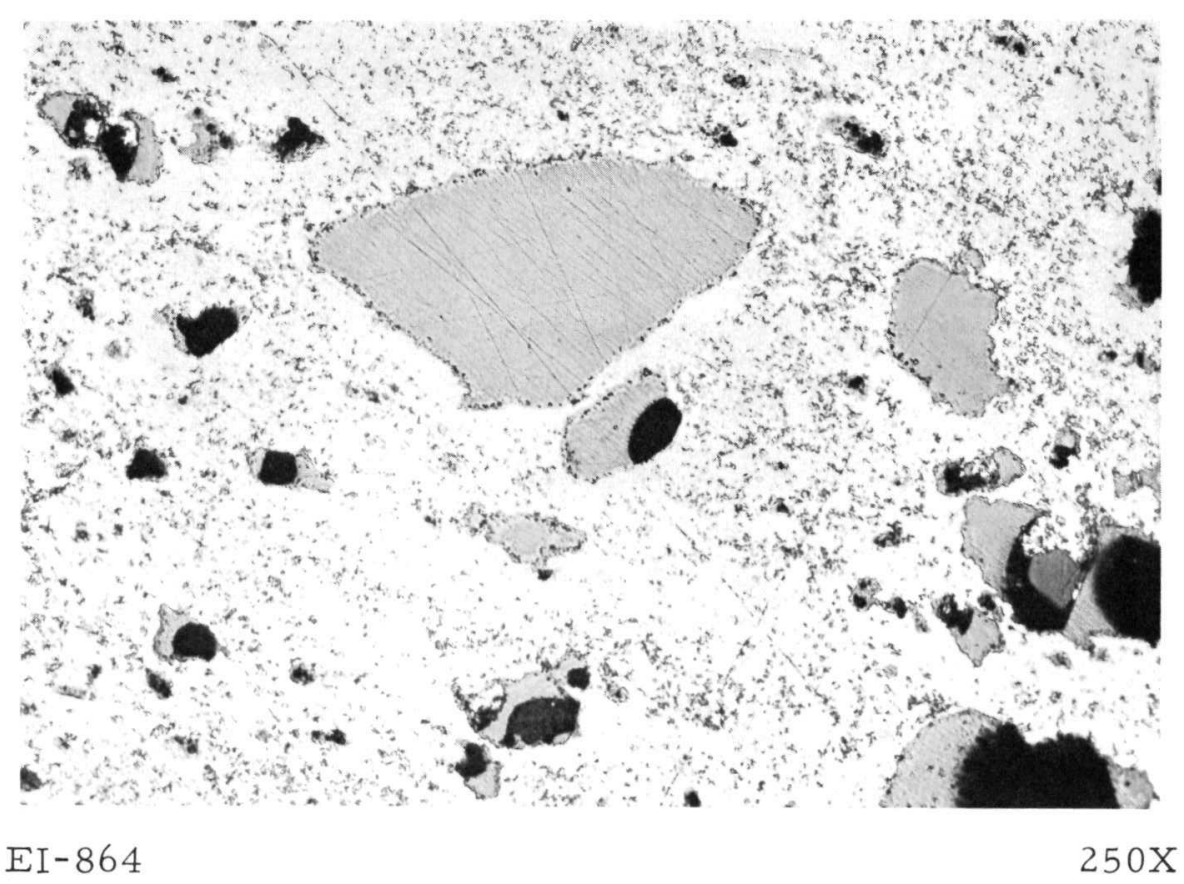

Figure 10. Specimen ED-1 after Irradiation. Note sintering in $\mathrm{U}_{3} \mathrm{O}_{8}$ particles. Sample in as-polished condition.

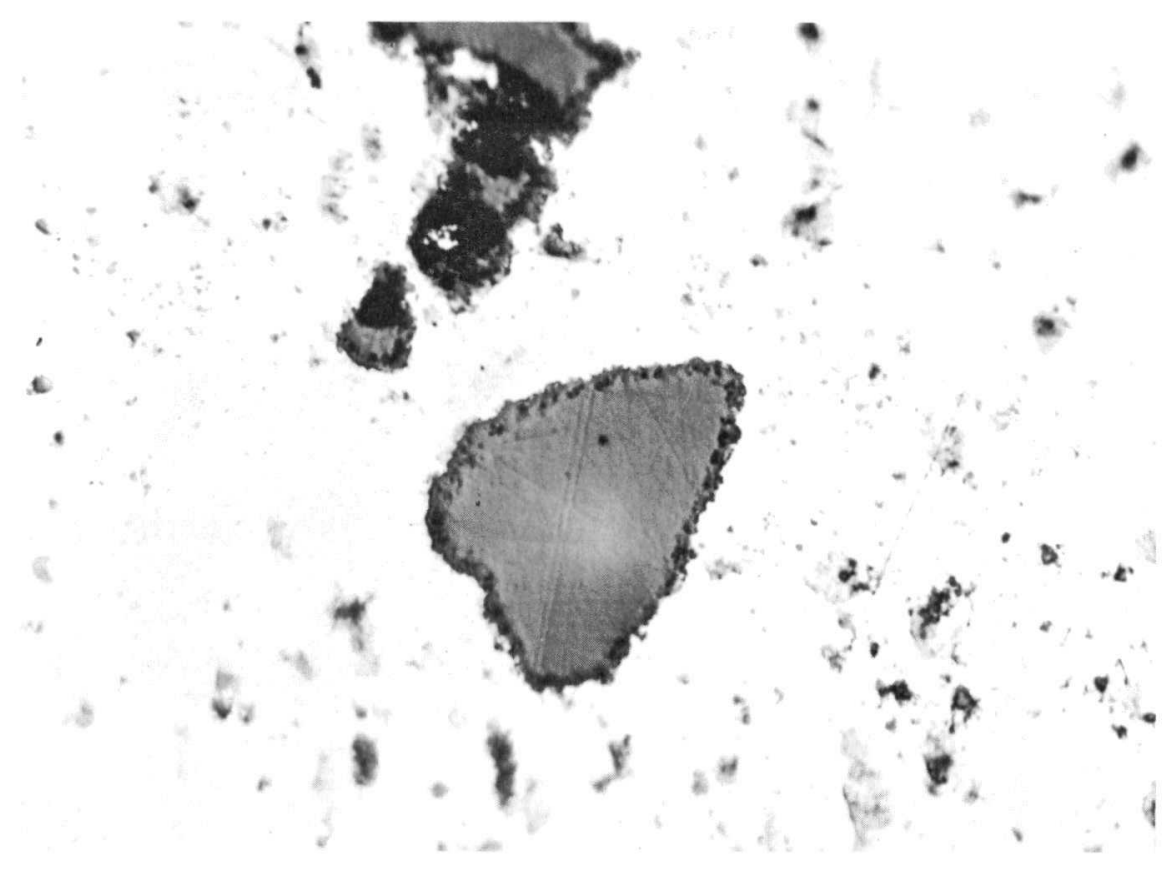

EI-795

Figure 11. Specimen ED-l after Irradiation. Note sintering in $\mathrm{U}_{3} \mathrm{O}_{8}$ particle. Sample in as-polished condition. 


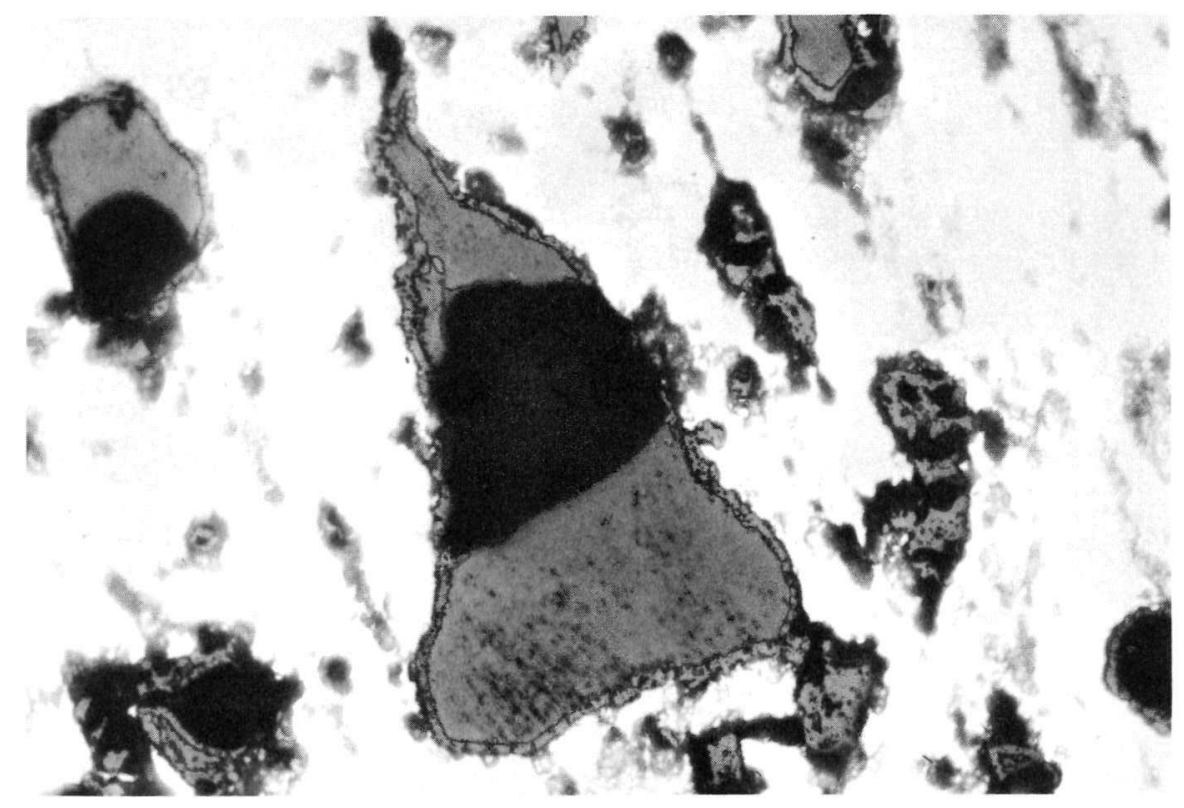

EI-865

$500 \mathrm{X}$

Figure 12. Specimen ED-1 after Irradiation. Specimen etched in $2 \% \mathrm{HF}$ solution, showing zone surrounding particle.
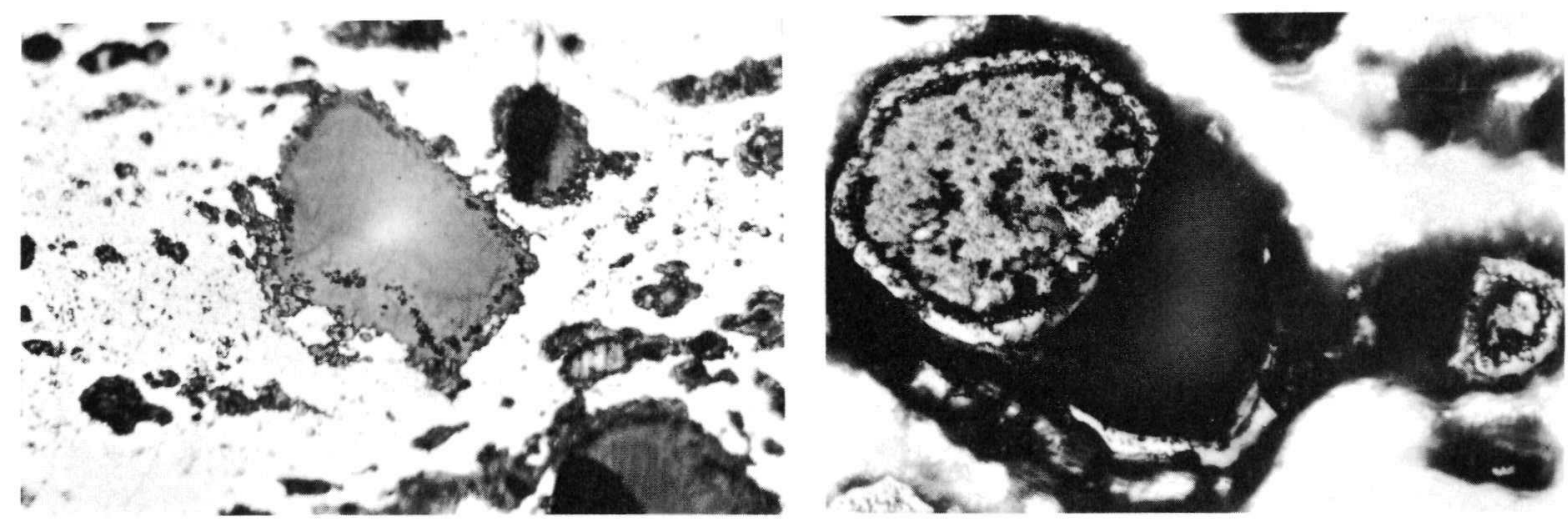

EI-866

$250 X$ EI-796

$500 x$

Figure 13. Specimen ED-7 after Ir- Figure 14. Specimen ED-7 after Irradiation. As-polished condition. radiation. Specimen etched in $2 \% \mathrm{HF}$ solution. Porosity due to burnup.

minimum temperature of approximately $800^{\circ} \mathrm{C}$ necessary to initiate sintering of the oxide. This low-temperature sintering phenomena, called radiation sintering, has been observed before.(9-11) The mechanism by which it occurs, however, is not thoroughly understood.(12) The fact that shrinkage occurred suggests that either lattice diffusion or plastic flow is an important mechanism 
involved in the sintering process. The lattice diffusion model, discussed by Burke,(13) seems the most reasonable of the two. The low irradiation temperature may have enhanced diffusion rates by producing an increased concentration of vacancy-interstitial pairs or by changing the location of sinks for vacancies to migrate.

Examination of the figures also reveals that the porosity within the irradiated particles was concentrated at the outer edges. As can be seen in Figure 12, the porosity may concentrate in apparent reaction zones surrounding the particles.

\section{B. Postirradiation Annealing}

The results of the annealing studies are tabulated in Table VI. Annealing temperatures up to $365^{\circ} \mathrm{C}$ produced initial volume increases of between 0.5 to 1 percent $\Delta \mathrm{V}$. However, after $360 \mathrm{hr}$ the measured densities were close to the pre-test values and indicate no measurable change in volume at that time. Volume increases of 1 and 4 percent were observed with samples annealed for approximately $500 \mathrm{hr}$ at $500^{\circ} \mathrm{C}$ and $550^{\circ} \mathrm{C}$, respectively. Figure 15 shows that specimen ED-6, annealed at $550^{\circ} \mathrm{C}$, had

Table ZI

ANNEALING HISTORY OF IRRADIATED $39 \mathrm{~W} / 0 \mathrm{U}_{3} \mathrm{O}_{8}$-ALUMINUM DISPERSION SPECIMENS

\begin{tabular}{|c|c|c|c|c|c|c|c|c|c|c|c|}
\hline \multirow{2}{*}{ Specimen } & \multicolumn{2}{|c|}{ Burnup } & \multirow{2}{*}{$\begin{array}{l}\text { Annealing } \\
\text { Temp, }{ }^{\circ} \mathrm{C}(\mathrm{a})\end{array}$} & \multirow{2}{*}{$\begin{array}{l}\text { Time at } \\
\text { Temp, hr }\end{array}$} & \multirow{2}{*}{$\begin{array}{l}\text { Cumulative } \\
\text { Time at } \\
\text { Temp, hr }\end{array}$} & \multirow{2}{*}{$\underset{g}{\text { Weight, }}$} & \multirow{2}{*}{$\begin{array}{l}\text { Density, }{ }^{(b)} \\
\text { g/cc }\end{array}$} & \multirow{2}{*}{$\begin{array}{c}\text { Total } \\
\% \Delta V^{(f)}\end{array}$} & \multicolumn{3}{|c|}{ Dimensions, ${ }^{(b)}$ in. } \\
\hline & $\begin{array}{c}\text { (Fissions/cc) } \\
\times 10^{-20}\end{array}$ & $\% U^{235}$ & & & & & & & Length & Width & Thickness \\
\hline ED-6 & 0.95 & 19.6 & 550 & $\begin{array}{r}0 \\
24 \\
69 \\
115 \\
115 \\
94 \\
94\end{array}$ & $\begin{array}{r}0 \\
24 \\
93 \\
208 \\
323 \\
417 \\
511\end{array}$ & $\begin{array}{l}4.815^{(d)} \\
4.819 \\
4.919(\mathrm{c}) \\
5.756(\mathrm{c}) \\
5.937(\mathrm{e}) \\
5.992 \\
6.018\end{array}$ & $\begin{array}{l}3.383^{(\mathrm{d})} \\
3.382 \\
3.308^{(\mathrm{C})} \\
3.990^{(\mathrm{C})} \\
2.960^{(\mathrm{e})} \\
2.962 \\
2.956\end{array}$ & $\begin{array}{l}- \\
\text { NMC } \\
+1.1 \\
+4.9 \\
+4.8 \\
+4.2 \\
+4.2\end{array}$ & $\begin{array}{l}1.028 \\
1.034 \\
1.051 \\
1.186 \\
1.210 \\
1.202 \\
1.199\end{array}$ & $\begin{array}{c}0.887 \\
0.887 \\
0.899 \\
0.929-1.122 \\
0.945-1.104 \\
0.966-1.087 \\
0.962-1.101\end{array}$ & $\begin{array}{l}0.094 \\
0.095 \\
0.096 \\
0.118 \\
0.118 \\
0.115 \\
0.117\end{array}$ \\
\hline ED-8 & 0.80 & 16.5 & 500 & $\begin{array}{r}0 \\
24 \\
69 \\
116 \\
115 \\
209\end{array}$ & $\begin{array}{r}0 \\
24 \\
93 \\
209 \\
324 \\
533\end{array}$ & $\begin{array}{l}4.674(c) \\
4.674(c) \\
4.678 \\
4.679 \\
4.693(c) \\
4.739(c)\end{array}$ & $\begin{array}{l}3.379(\mathrm{c}) \\
3.395(\mathrm{c}) \\
3.392 \\
3.393 \\
3.373(\mathrm{c}) \\
3.316(\mathrm{c})\end{array}$ & $\begin{array}{l}- \\
-0.5 \\
-0.4 \\
-0.4 \\
\text { NMC } \\
+1.1\end{array}$ & $\begin{array}{l}0.998 \\
1.006 \\
0.999 \\
1.002 \\
1.006 \\
1.011\end{array}$ & $\begin{array}{l}0.885 \\
0.884 \\
0.885 \\
0.885 \\
0.888 \\
0.898\end{array}$ & $\begin{array}{l}0.094 \\
0.095 \\
0.094 \\
0.094 \\
0.095 \\
0.093\end{array}$ \\
\hline ED-9 & 0.71 & 14.6 & 365 & $\begin{array}{r}0 \\
24 \\
72 \\
144 \\
120\end{array}$ & $\begin{array}{r}0 \\
24 \\
96 \\
240 \\
360\end{array}$ & $\begin{array}{l}4.602 \\
4.571 \\
4.566 \\
4.566 \\
4.561\end{array}$ & $\begin{array}{l}3.363 \\
3.403 \\
3.396 \\
3.391 \\
3.403\end{array}$ & $\begin{array}{c}- \\
- \\
+0.2 \\
+0.4 \\
\text { NMC }\end{array}$ & $\begin{array}{l}0.997 \\
0.987 \\
0.992 \\
0.988 \\
0.989\end{array}$ & $\begin{array}{l}0.887 \\
0.887 \\
0.890 \\
0.886 \\
0.885\end{array}$ & $\begin{array}{l}0.095 \\
0.094 \\
0.093 \\
0.095 \\
0.092\end{array}$ \\
\hline$E D-3$ & 0.54 & 10.5 & 210 & $\begin{array}{r}0 \\
24 \\
72 \\
146 \\
120\end{array}$ & $\begin{array}{r}0 \\
24 \\
96 \\
242 \\
362\end{array}$ & $\begin{array}{l}4.656 \\
4.627 \\
4.630 \\
4.628 \\
4.624\end{array}$ & $\begin{array}{l}3.456 \\
3.473 \\
3.441 \\
3.474 \\
3.476\end{array}$ & $\begin{array}{c}- \\
- \\
+0.9 \\
\text { NMC } \\
\text { NMC }\end{array}$ & $\begin{array}{l}1.006 \\
0.980 \\
0.980 \\
0.982 \\
0.981\end{array}$ & $\begin{array}{l}0.889 \\
0.888 \\
0.885 \\
0.884 \\
0.882\end{array}$ & $\begin{array}{l}0.094 \\
0.094 \\
0.094 \\
0.094 \\
0.093\end{array}$ \\
\hline
\end{tabular}

(a) The temperature did not vary more than $\pm 10^{\circ} \mathrm{C}$ at any time during the test.

(b) The precision of the measurements is: weight, $\pm 0.002 \mathrm{~g}$; density, $\pm 0.004 \mathrm{~g} / \mathrm{cc}$; dimensions, $\pm 0.001 \mathrm{in}$.

(c) Represents the average of two measurements.

(d) Represents the average of six measurements.

(e) Represents the average of three measurements.

(f) Calculated from the expression $\% \Delta V=\left[\left(\frac{\rho_{\mathrm{i}}}{\rho_{\mathrm{f}}}\right)-\mathrm{l}\right] 100$, where $\rho_{\mathrm{i}}$ and $\rho_{\mathrm{f}}$ are the initial and final densities, respectively. 
cracked badly. The cracking was first noticed at the close of the third

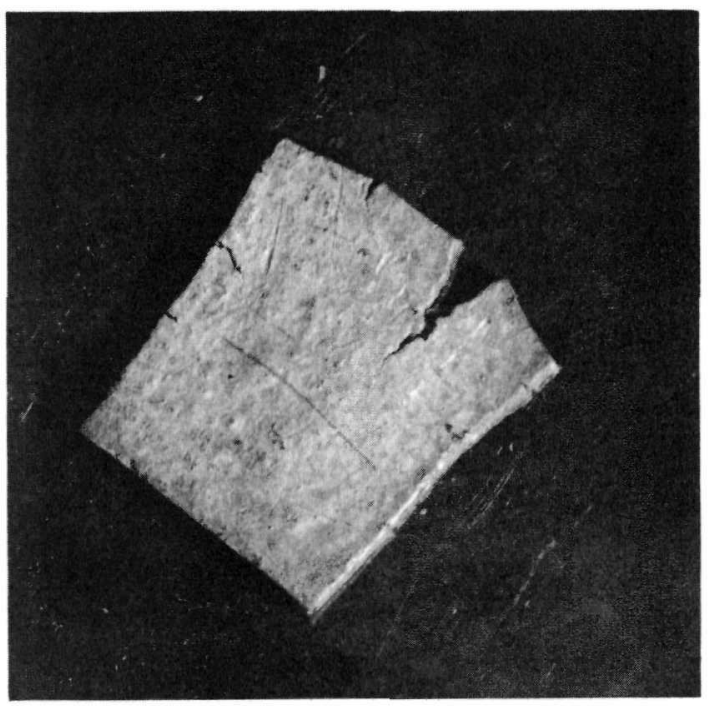

EI -185

$1 \mathrm{X}$

Figure 15. Specimen ED-6 at Conclusion of Annealing Study. annealing period, at which time the specimen had accumulated $208 \mathrm{hr}$ at temperature. The cracks did not seem to enlarge appreciably with further annealing. The other specimens were in good condition at the close of the tests. The precision of the weight and density measurements was determined by a series of fifteen measurements made on a similar irradiated but unannealed specimen. The data indicate a standard deviation of $\pm 0.002 \mathrm{~g}$ for weight and of $\pm 0.004 \mathrm{~g} / \mathrm{cc}$ for density measurements.

The examination of samples ED-3 and ED-9 showed varying amounts of surface oxide had formed during storage of the specimens after irradiation. Attempts at removing this surface oxide prior to annealing were not completely successful. However, examination of the specimens showed that the oxide had been removed during the initial annealing period. This was also indicated by the decrease in weight and increase in density of the specimens. The weights and densities after the initial annealing period compare favorably with the measurements taken immediately after irradiation. Therefore, in calculating the percent change in volume, the initial density of specimens ED-3 and ED-9 was taken as more truly represented by the densities after the first annealing period, and these were used in calculating the subsequent volume changes.

Specimens ED-6 and ED-8 with their respective control samples C-4 and C-3 increased in weight as the tests progressed. It was apparent that the salt was adhering to the samples. Therefore, where necessary, the measured weights and volumes given in Tables VI and VII were corrected, as shown in the appendix, to account for the salt. The corrected weights and volumes were then used to calculate the density of the specimen, and this density was used to determine any change which occurred due to the additional annealing time. The density of the salt was taken as $2.18 \mathrm{~g} / \mathrm{cc}$.

The data for the unirradiated control samples, annealed concurrently with the test specimens, are given in Table VII. It can be seen from the data that the unirradiated specimens decreased in density. The higher the annealing temperature, the greater the decrease in density or increase in volume. These volume increases are associated, in a way not fully understood, with the reaction between the $\mathrm{U}_{3} \mathrm{O}_{8}$ particles and the 
aluminum matrix. The quantity of hydrogen present in the specimens was unknown. However, if it was significant it could also have contributed to the observed volume increases.

Table VIII

ANNEALING HISTORY OF UNIRRADIATED 39 w/0 U $U_{3} \mathrm{O}_{8}$-ALUMINUM DISPERSION SPECIMENS

\begin{tabular}{|c|c|c|c|c|c|c|c|}
\hline Specimen & $\begin{array}{l}\text { Annealing } \\
\text { Temp, (a) }{ }^{\circ} \mathrm{C}\end{array}$ & $\begin{array}{l}\text { Time at } \\
\text { Temp, hr }\end{array}$ & $\begin{array}{c}\text { Cumulative } \\
\text { Time at } \\
\text { Temp, hr }\end{array}$ & $\begin{array}{l}\text { Weight, } \\
\mathrm{g}\end{array}$ & $\begin{array}{l}\text { Density, }{ }^{(b)} \\
\mathrm{g} / \mathrm{cc}\end{array}$ & $\begin{array}{c}\text { Total } \\
\% \Delta \mathrm{v}^{\prime}(\mathrm{d})\end{array}$ & $\begin{array}{c}\text { Thickness, } \\
\text { in. }\end{array}$ \\
\hline$C-4$ & 550 & $\begin{array}{r}0 \\
24 \\
69 \\
115 \\
115 \\
94 \\
94\end{array}$ & $\begin{array}{r}0 \\
24 \\
93 \\
208 \\
323 \\
417 \\
511\end{array}$ & $\begin{array}{l}10.740 \\
10.777 \\
10.800 \\
10.818 \\
10.853^{(c)} \\
10.853 \\
10.874\end{array}$ & $\begin{array}{l}3.374 \\
3.262 \\
3.260 \\
3.263 \\
3.250 \text { (c) } \\
3.258 \\
3.259\end{array}$ & $\begin{array}{l}- \\
+3.3 \\
+3.2 \\
+3.0 \\
+3.3 \\
+3.0 \\
+2.9\end{array}$ & $0.101-0.103$ \\
\hline$C-3$ & 500 & $\begin{array}{r}0 \\
24 \\
69 \\
116 \\
115 \\
209\end{array}$ & $\begin{array}{r}0 \\
24 \\
93 \\
209 \\
324 \\
533\end{array}$ & $\begin{array}{l}9.182 \\
9.202(\mathrm{c}) \\
9.226 \\
9.243 \\
9.251^{(c)} \\
9.268\end{array}$ & $\begin{array}{l}3.376 \\
3.319^{(c)} \\
3.320 \\
3.329 \\
3.324(c) \\
3.329\end{array}$ & $\begin{array}{l}- \\
+1.6 \\
+1.4 \\
+1.1 \\
+1.1 \\
+0.9\end{array}$ & $0.97-0.99$ \\
\hline$c-2$ & 365 & $\begin{array}{r}0 \\
24 \\
72 \\
144 \\
120\end{array}$ & $\begin{array}{r}0 \\
24 \\
96 \\
240 \\
360\end{array}$ & $\begin{array}{l}10.105 \\
10.107 \\
10.107 \\
10.110 \\
10.109\end{array}$ & $\begin{array}{l}3.382 \\
3.370 \\
3.358 \\
3.352 \\
3.360\end{array}$ & $\begin{array}{l}- \\
+0.4 \\
+0.7 \\
+0.9 \\
+0.6\end{array}$ & $0.096-0.100$ \\
\hline$C-1$ & 210 & $\begin{array}{r}0 \\
24 \\
72 \\
146 \\
120\end{array}$ & $\begin{array}{r}0 \\
24 \\
96 \\
242 \\
362\end{array}$ & $\begin{array}{l}9.258 \\
9.257 \\
9.263 \\
9.259 \\
9.257\end{array}$ & $\begin{array}{l}3.382 \\
3.376 \\
3.366 \\
3.363 \\
3.369\end{array}$ & $\begin{array}{l}- \\
+0.2 \\
+0.5 \\
+0.6 \\
+0.4\end{array}$ & $0.095-0.099$ \\
\hline
\end{tabular}

(a) The temperature did not vary more than $\pm 10^{\circ} \mathrm{C}$ at any time during the test.

(b) The precision of the measurements is: weight $\pm 0.002 \mathrm{~g}$; density, $\pm 0.004 \mathrm{~g} / \mathrm{cc}$; thickness, $\pm 0.001 \mathrm{in}$.

(c) Represents the average of two measurements.

(d) Calculated from the expression $\% \Delta V=\left[\left(\frac{\rho_{i}}{\rho_{f}}\right)-1\right] 100$ where $\rho_{i}$ and $\rho_{f}$ are the initial and final densities respectively.

C. $\mathrm{U}_{3} \mathrm{O}_{8}$-Aluminum Reaction

It has been observed that $\mathrm{U}_{3} \mathrm{O}_{8}$ and $\mathrm{UO}_{2}$ react with aluminum at temperatures between 500 and $600^{\circ} \mathrm{C}$. (14-16) $\mathrm{UO}_{2}$ and $\mathrm{Al}_{2} \mathrm{O}_{3}$ form by the aluminum reduction of the $\mathrm{U}_{3} \mathrm{O}_{8}$. The $\mathrm{UO}_{2}$ is also reduced by the aluminum with the formation of $\mathrm{U}-\mathrm{Al}$ intermetallics and more $\mathrm{Al}_{2} \mathrm{O}_{3}$. The reaction proceeds in steps with the eventual conversion of all the uranium present to the intermetallic compound $\mathrm{UAl}_{4}$. Calculations based upon the balanced equations and theoretical densities of the reactants and products indicate that overall volume decreases should accompany the reaction. These decreases have not been observed, however. In fact, the reaction produces sizable volume increases. This apparent anomaly may be explained if one assumes that the reaction products are somewhat less than theoretically dense. This may be possible if the reaction proceeds by the Kirkendall mechanism. 
Sections from both the irradiated and unirradiated $\mathrm{U}_{3} \mathrm{O}_{8}-$ aluminum specimens used in the annealing studies were dissolved in hot concentrated sodium hydroxide solution. Each oxide residue was washed and filtered; and a sample taken for X-ray diffraction analysis. X-ray diffraction analyses of the $\mathrm{U}_{3} \mathrm{O}_{8}$ obtained from the ir radiated specimens were not successful because of film fogging due to their activity. The results of the analyses on the unirradiated specimens are given in Table VIII. The presence of $\mathrm{UO}_{2}$ was detected in all cases. The data indicate that the concentration of $\mathrm{UO}_{2}$ was dependent upon temperature and time. In some instances the metallographic examination also revealed a dependence upon particle size and shape. However, for the most part, the metallographic examinations at magnifications up to $750 \mathrm{X}$ did not reveal any reaction zones surrounding the $\mathrm{U}_{3} \mathrm{O}_{8}$ particles. These results are in general agreement with other experiments $(14-16)$ in which it was also demonstrated that the oxide manufacturing process and additives such as $\mathrm{TiO}_{2}$ or $\mathrm{CaF}_{2}$ affect the reaction. The relative quantities of each phase present were estimated based on the observed line intensities.

\section{Table VIII}

\section{X-RAY DIFFRACTION ANALYSES OF UNIRRADIATED $\mathrm{U}_{3} \mathrm{O}_{8}$-ALUMINUM CONTROL SPECIMENS}

\begin{tabular}{|c|c|c|}
\hline $\begin{array}{l}\text { Specimen } \\
\text { No. }\end{array}$ & $\begin{array}{l}\text { Annealing } \\
\text { History }\end{array}$ & Phases Present \\
\hline $\mathrm{U}$ & None & $90 \% \mathrm{U}_{3} \mathrm{O}_{8}+10 \% \mathrm{UO}_{2}$ \\
\hline$C-1$ & $362 \mathrm{hr}$ at $210^{\circ} \mathrm{C}$ & $85 \% \mathrm{U}_{3} \mathrm{O}_{8}+15 \% \mathrm{UO}_{2}$ \\
\hline$C-2$ & $360 \mathrm{hr}$ at $365^{\circ} \mathrm{C}$ & $80 \% \mathrm{U}_{3} \mathrm{O}_{8}+20 \% \mathrm{UO}_{2}$ \\
\hline$C-3$ & $533 \mathrm{hr}$ at $500^{\circ} \mathrm{C}$ & $\begin{array}{l}60 \% \mathrm{U}_{3} \mathrm{O}_{8}+40 \% \mathrm{UO}_{2}+ \\
\text { trace } \mathrm{UAl}_{3}\end{array}$ \\
\hline$C-4$ & 511 hr at $550^{\circ} \mathrm{C}$ & $\begin{array}{l}40 \% \mathrm{U}_{3} \mathrm{O}_{8}+50 \% \mathrm{UO}_{2}+ \\
10 \% \mathrm{UAl}_{3}+\text { trace of } \\
\mathrm{UAl}_{4}\end{array}$ \\
\hline
\end{tabular}

The dependence of the $\mathrm{UO}_{2}$ concentration upon temperature can be seen by comparing the results of annealing studies conducted for approximately equivalent times but at different temperatures. The quantity of $\mathrm{UO}_{2}$ increased as the annealing temperature increased. The as fabricated sample had $10 \% \mathrm{UO}_{2}$ present which probably formed during the soaking period of 12 to $14 \mathrm{hr}$ at $480^{\circ} \mathrm{C}$ prior to extrusion, whereas the $\mathrm{UO}_{2}$ concentration had increased to $40 \%$ after $533 \mathrm{hr}$ at $500^{\circ} \mathrm{C}$. Thus, the quantity of $\mathrm{UO}_{2}$ increases as the length of time at a given temperature increases. The data also indicate that reduction of the $\mathrm{UO}_{2}$ begins after about $40 \%$ of the $\mathrm{U}_{3} \mathrm{O}_{8}$ has been reduced. 


\section{Discussion}

In its initial stages the reaction between aluminum and $\mathrm{U}_{3} \mathrm{O}_{8}$ produces $\mathrm{UO}_{2}$ and, as the reduction of $\mathrm{UO}_{2}$ progresses, $\mathrm{U}-\mathrm{Al}$ intermetallics begin to form. This reaction leads to measurable volume increases.

Although $\mathrm{X}$-ray diffraction analyses could not be run with the irradiated specimens to verify the presence of $\mathrm{UO}_{2}$, it is speculated that the volume increases noted for the ir radiated specimens can, at least in part, be attributed to this reaction also. In particular, specimens ED-3, ED-8, and ED-9 along with their unirradiated controls exhibited similar volume increases as a result of the annealing. Therefore, it is speculated that the observed increases were due chiefly to the $\mathrm{U}_{3} \mathrm{O}_{8}$-aluminum reaction, plus the agglomeration of any residual hydrogen, and not to the agglomeration of fission product gases.

Specimen ED-6 exhibited a volume increase slightly in excess of that associated with the $\mathrm{U}_{3} \mathrm{O}_{8}$-aluminum reactions. This excess was probably the result of fission gas agglomeration. ED-6 also cracked badly during the course of the annealing study, for reasons not known. However, it is not believed to be associated with either the $\mathrm{U}_{3} \mathrm{O}_{8}$-aluminum reactions or fission gas agglomeration. It might be related to prior fabrication history in some way.

The $\mathrm{U}_{3} \mathrm{O}_{8}$-aluminum dispersion system seems resistant to gross swelling caused by fission gas agglomeration for burnups up to at least $1.0 \times 10^{20}$ fissions per $\mathrm{cc}$ and temperatures up to $550^{\circ} \mathrm{C}$. Small volume increases will occur with fuel operated between $210^{\circ} \mathrm{C}$ and $550^{\circ} \mathrm{C}$ due to the aluminum reduction of the $\mathrm{U}_{3} \mathrm{O}_{8}$ and intermetallic formation. After approximately $500 \mathrm{hr}$, this amounts to about $1 \%$ at $500^{\circ} \mathrm{C}$ and to $3 \%$ at $550^{\circ} \mathrm{C}$.

II. Aluminum-17.3 w/o Uranium Alloy

A. Postirradiation Annealing

Figure 4 illustrates the geometry of the specimens used in the annealing studies. The experimental procedures were identical with those described in the preceding section for the $\mathrm{U}_{3} \mathrm{O}_{8}$-aluminum dispersions; in fact, the alloy and dispersion specimens were annealed together. For each annealing temperature, the specimens were chosen with approximately equivalent burnups so that information would be obtained, not only about the swelling temperature of each material, but also sufficient for comparing the two systems. 
The results of the annealing studies on the irradiated specimens are tabulated in Table IX. Volume increases occurred in all specimens annealed at $550^{\circ} \mathrm{C}$. As can be seen in Figures 16 to 18 , at a burnup of $5.9 \times 10^{20}$ fissions per cc swelling occurred as severe localized blistering whereas at a burnup of $1.4 \times 10^{20}$ fissions per cc the volume increase was uniform in nature. Specimens with burnups ranging from $0.41 \times 10^{20}$ to $1.2 \times 10^{20}$ fissions per cc showed a tendency towards a slight uniform increase in volume for annealing temperatures in the range from $210^{\circ} \mathrm{C}$ to $500^{\circ} \mathrm{C}$. The precision of the weight and density measurements was determined by a series of fifteen measurements made on similar irradiated but unannealed material. The data indicate a standard deviation of $\pm 0.002 \mathrm{~g}$ for the weight and of $\pm 0.003 \mathrm{~g} / \mathrm{cc}$ for the density measurements.

Table IX

ANNEALING HISTORY OF IRRADIATED ALUMINUM-17.3 w/O URANIUM ALLOY SPECIMENS

\begin{tabular}{|c|c|c|c|c|c|c|c|c|c|c|c|}
\hline \multirow{2}{*}{ Specimen } & \multicolumn{2}{|c|}{ Burnup } & \multirow{2}{*}{$\begin{array}{l}\text { Annealing } \\
\text { Temp, (a) }{ }^{\circ} \mathrm{C}\end{array}$} & \multirow{2}{*}{$\begin{array}{l}\text { Time at } \\
\text { Temp, hr }\end{array}$} & \multirow{2}{*}{$\begin{array}{l}\text { Cumulative } \\
\text { Time at } \\
\text { Temp, hr }\end{array}$} & \multirow{2}{*}{$\begin{array}{c}\text { Weight, (b) } \\
g\end{array}$} & \multirow{2}{*}{$\begin{array}{l}\text { Density, } \\
\mathrm{g} / \mathrm{cc}\end{array}$} & \multirow{2}{*}{$\begin{array}{c}\text { Total } \\
\% \Delta \text { Vle) }\end{array}$} & \multicolumn{3}{|c|}{ Dimensions, ${ }^{(b)}$ in. } \\
\hline & $\begin{array}{c}\text { (Fissions/cc) } \\
\times 10^{-20}\end{array}$ & $\% U^{235}$ & & & & & & & Length & Width & Thickness \\
\hline W-12-TE & 5.9 & 45.1 & 550 & $\begin{array}{c}0 \\
94 \\
1.5 \\
2 \\
3.5 \\
3 \\
46 \\
36 \\
114 \\
71\end{array}$ & $\begin{array}{c}0 \\
94 \\
95.5 \\
97.5 \\
101 \\
104 \\
150 \\
186 \\
300 \\
371\end{array}$ & $\begin{array}{l}10.405 \\
10.430 \\
10.422 \\
10.434 \\
10.478 \\
10.525 \\
10.631 \\
10.753 \\
10.928 \\
11.065\end{array}$ & $\begin{array}{l}2.856 \\
2.426 \\
2.419 \\
2.416 \\
2.413 \\
2.386 \\
2.360 \\
2.352 \\
2.321 \\
2.308\end{array}$ & $\begin{array}{l}- \\
+17.7 \\
+18.0 \\
+18.2 \\
+18.3 \\
+19.5 \\
+20.8 \\
+21.1 \\
+22.6 \\
+23.3\end{array}$ & $\begin{array}{l}2.055 \\
2.082 \\
2.079 \\
2.076 \\
2.076 \\
2.087 \\
2.074 \\
2.088 \\
2.094 \\
2.101\end{array}$ & $\begin{array}{c}1.001 \\
0.989 \\
0.986 \\
0.981-1.003 \\
0.986-1.006 \\
0.980-1.003 \\
0.977-1.009 \\
0.980-1.008 \\
0.983-1.021 \\
0.984-1.021\end{array}$ & $\begin{array}{c}0.111 \\
0.112-0.219 \\
0.119-0.220 \\
0.107-0.209 \\
0.128-0.215 \\
0.131-0.228 \\
0.128-0.230 \\
0.126-0.228 \\
0.139-0.244 \\
0.133-0.249\end{array}$ \\
\hline W-12-TES & 5.9 & 45.1 & 550 & $\begin{array}{l}0 \\
1.5 \\
2 \\
3.5 \\
3 \\
94 \\
46 \\
36 \\
114 \\
71\end{array}$ & $\begin{array}{c}0 \\
1.5 \\
3.5 \\
7 \\
10 \\
104 \\
150 \\
186 \\
300 \\
371\end{array}$ & $\begin{array}{l}4.986 \\
4.952 \\
4.945 \\
4.944 \\
4.944 \\
4.997 \\
5.020 \\
5.033 \\
5.058 \\
5.071\end{array}$ & $\begin{array}{l}2.809 \\
2.791 \\
2.767 \\
2.760 \\
2.744 \\
2.667 \\
2.636 \\
2.627 \\
2.616 \\
2.616\end{array}$ & $\begin{array}{l}- \\
+0.6 \\
+1.5 \\
+1.8 \\
+2.4 \\
+5.3 \\
+6.6 \\
+6.9 \\
+7.4 \\
+7.4\end{array}$ & $\begin{array}{l}2.051 \\
2.054 \\
2.042 \\
2.045 \\
2.051 \\
2.072 \\
2.011 \\
2.070 \\
2.078 \\
2.076\end{array}$ & $\begin{array}{c}0.497 \\
0.493 \\
0.491-0.505 \\
0.487-0.505 \\
0.490-0.504 \\
0.504-0.510 \\
0.502-0.511 \\
0.502-0.513 \\
0.497-0.552 \\
0.505-0.514\end{array}$ & $\begin{array}{c}0.104 \\
0.104 \\
0.096-0.106 \\
0.098-0.105 \\
0.098-0.105 \\
0.101-0.133 \\
0.098-0.124 \\
0.095-0.117 \\
0.104-0.114 \\
0.097-0.133\end{array}$ \\
\hline$W-12-6$ & 1.4 & 10.8 & 550 & $\begin{array}{r}0 \\
24 \\
69 \\
115 \\
115 \\
94 \\
94\end{array}$ & $\begin{array}{r}0 \\
24 \\
93 \\
208 \\
323 \\
417 \\
511\end{array}$ & $\begin{array}{l}10.415(\mathrm{c}) \\
10.382 \\
10.367 \\
10.353 \\
10.364(\mathrm{~d}) \\
10.354 \\
10.356\end{array}$ & $\begin{array}{l}2.890^{(\mathrm{c})} \\
2.887 \\
2.881 \\
2.881 \\
2.865 \text { (d) } \\
2.860 \\
2.850\end{array}$ & $\begin{array}{l}- \\
\text { NMC } \\
+0.3 \\
+0.3 \\
+0.9 \\
+1.0 \\
+1.4\end{array}$ & $\begin{array}{l}1.024 \\
1.024 \\
1.024 \\
1.027 \\
1.031 \\
1.032 \\
1.034\end{array}$ & $\begin{array}{l}2.001 \\
1.999 \\
2.004 \\
2.008 \\
2.000 \\
2.003 \\
2.004\end{array}$ & $\begin{array}{l}0.105 \\
0.106 \\
0.105 \\
0.103 \\
0.103 \\
0.102 \\
0.102\end{array}$ \\
\hline$W-12-5$ & 1.2 & 8.8 & 500 & $\begin{array}{r}0 \\
24 \\
69 \\
116 \\
115 \\
209\end{array}$ & $\begin{array}{r}0 \\
24 \\
93 \\
209 \\
324 \\
533\end{array}$ & $\begin{array}{l}10.141^{(d)} \\
10.120(d) \\
10.111 \\
10.102 \\
10.103 \text { (d) } \\
10.093\end{array}$ & $\begin{array}{l}2.889^{(d)} \\
2.896^{(d)} \\
2.895 \\
2.896 \\
2.891^{(d)} \\
2.892\end{array}$ & $\begin{array}{l}- \\
- \\
\text { NMC } \\
\text { NMC } \\
+0.2 \\
+0.1\end{array}$ & $\begin{array}{l}1.005 \\
1.004 \\
1.006 \\
1.005 \\
1.002 \\
1.005\end{array}$ & $\begin{array}{l}2.000 \\
1.998 \\
1.998 \\
1.996 \\
1.996 \\
1.999\end{array}$ & $\begin{array}{l}0.105 \\
0.103 \\
0.103 \\
0.103 \\
0.103 \\
0.103\end{array}$ \\
\hline$W-12-4$ & 0.77 & 5.8 & 365 & $\begin{array}{r}0 \\
24 \\
72 \\
144 \\
120\end{array}$ & $\begin{array}{r}0 \\
24 \\
96 \\
240 \\
360\end{array}$ & $\begin{array}{l}9.897 \\
9.887 \\
9.887 \\
9.885 \\
9.883\end{array}$ & $\begin{array}{l}2.904 \\
2.903 \\
2.891 \\
2.888 \\
2.896\end{array}$ & $\begin{array}{l}- \\
\text { NMC } \\
+0.4 \\
+0.6 \\
+0.3\end{array}$ & $\begin{array}{l}0.987 \\
0.990 \\
0.989 \\
0.989 \\
0.991\end{array}$ & $\begin{array}{l}1.996 \\
1.995 \\
1.995 \\
1.997 \\
1.995\end{array}$ & $\begin{array}{l}0.105 \\
0.104 \\
0.104 \\
0.104 \\
0.104\end{array}$ \\
\hline$W-12-1$ & 0.41 & 3.2 & 210 & $\begin{array}{r}0 \\
24 \\
72 \\
146 \\
120\end{array}$ & $\begin{array}{r}0 \\
24 \\
96 \\
242 \\
362\end{array}$ & $\begin{array}{l}10.293 \\
10.281 \\
10.380 \\
10.283 \\
10.277\end{array}$ & $\begin{array}{l}2.904 \\
2.903 \\
2.905 \\
2.898 \\
2.897\end{array}$ & $\begin{array}{l}- \\
\text { NMC } \\
\text { NMC } \\
+0.2 \\
+0.2\end{array}$ & $\begin{array}{l}1.022 \\
1.022 \\
1.022 \\
1.022 \\
1.020\end{array}$ & $\begin{array}{l}1.993 \\
1.991 \\
1.992 \\
1.993 \\
1.994\end{array}$ & $\begin{array}{l}0.104 \\
0.105 \\
0.104 \\
0.105 \\
0.103\end{array}$ \\
\hline
\end{tabular}

(a) The temperature did not vary more than $\pm 10^{\circ} \mathrm{C}$ at any time during the test.

(b) The precision of measurements is: weight, $\pm 0.002 \mathrm{~g}$; density, $\pm 0.003 \mathrm{~g} / \mathrm{cc}$; dimensions, $\pm 0.001 \mathrm{in}$.

(c) Is the average of six measurements.

(d) Is the average of two measurements.

(e) Based on the assumption of no weight change and calculated from the expression $\% \Delta V=\left[\left(\frac{\rho_{i}}{\rho_{f}}\right)-1\right] 100$, where $\rho_{i}$ and $\rho_{f}$ are the initial and
final densities, respectively. NMC means no measurable change. 


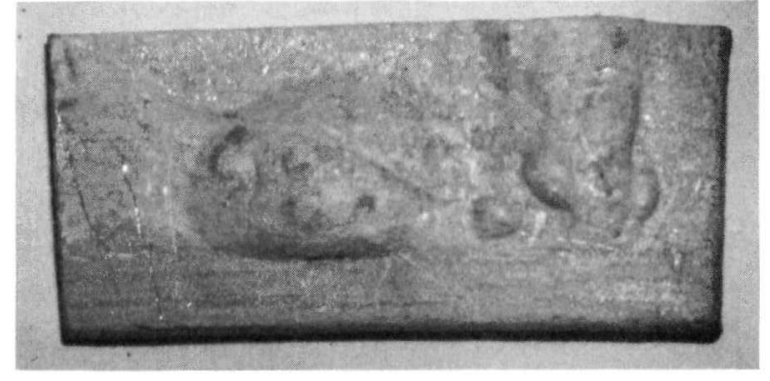

EI-229

Burnup

Annealing Conditions

$5.9 \times 10^{20}$ fissions/cc

371 hr at $550^{\circ} \mathrm{C}$ $\sim 1 \mathrm{X}$

Figure 16. Severe Blistering on Specimen W-12-TE.

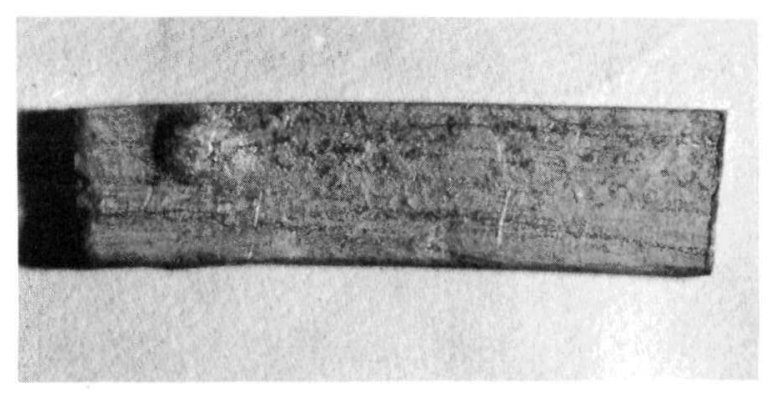

EI-223

Burnup Annealing Conditions

$5.9 \times 10^{20}$ fissions/cc $\sim 1 \mathrm{X}$ Figure 17. Blistering on Specimen W-12-TES.

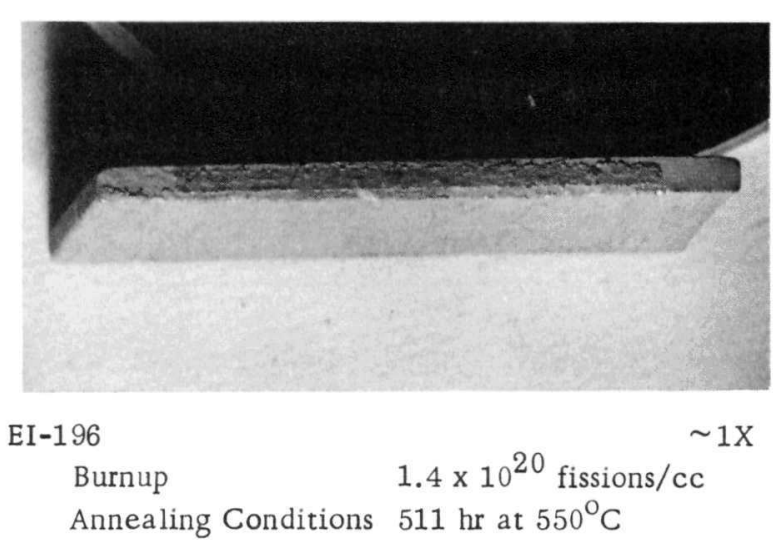

Figure 18. Growth of Fuel Core out of Cladding on Specimen $\mathrm{W}-12-6$.

Data on the unirradiated control specimens, given in Table $\mathrm{X}$, indicate a slight volume increase for annealing temperatures up to $365^{\circ} \mathrm{C}$. The cause of this increase in volume is not known. The significance of the increase, however, is questionable, as the data also indicate that similar material annealed at significantly higher temperatures had not swelled. The specimens were in excellent condition at the close of the tests. There was no evidence of any corrosive attack by the annealing salts.

The irradiated specimens had varying quantities of oxide present on their surfaces at the start of the tests. Most of the oxide was removed after the initial annealing period. However, specimens W-12-TE and W-12-TES retained some of their surface oxides and, in addition, picked up annealing salt, which accounts for the sizable weight increases which were noted. The measured weights and volumes, given in Table IX, were corrected to account for the salt and these corrected weights and volumes were used to calculate the density of the specimen. This corrected density was then used to determine any change which occurred due to annealing. The density of the salt was taken as $2.18 \mathrm{~g} / \mathrm{cc}$. 
Table Z

ANNEALING HISTORY OF UNIRRADIATED ALUMINUM-17.3 w/0 URANIUM ALLOY SPECIMENS

\begin{tabular}{|c|c|c|c|c|c|c|c|}
\hline Specimen & $\begin{array}{l}\text { Annealing } \\
\text { Temp, }(a)^{\circ} \mathrm{C}\end{array}$ & $\begin{array}{l}\text { Time at } \\
\text { Temp, hr }\end{array}$ & $\begin{array}{l}\text { Cumulative } \\
\text { Time at } \\
\text { Temp, hr }\end{array}$ & $\begin{array}{c}\text { Weight, } \\
\mathrm{g}\end{array}$ & $\begin{array}{l}\text { Density, (b) } \\
\text { g/cc }\end{array}$ & $\begin{array}{c}\text { Total } \\
\% \Delta V^{\prime}(c)\end{array}$ & $\begin{array}{c}\text { Thickness, } \\
\text { in. }\end{array}$ \\
\hline$C-44$ & 550 & $\begin{array}{r}0 \\
24 \\
69 \\
115 \\
115 \\
94 \\
94\end{array}$ & $\begin{array}{r}0 \\
24 \\
93 \\
208 \\
323 \\
417 \\
511\end{array}$ & $\begin{array}{l}13.568(d) \\
13.565 \\
13.560 \\
13.560 \\
13.570^{(d)} \\
13.563 \\
13.564\end{array}$ & $\begin{array}{l}2.834^{(\mathrm{d})} \\
2.838 \\
2.836 \\
2.840 \\
2.834^{(\mathrm{d})} \\
2.836 \\
2.835\end{array}$ & $\begin{array}{c}- \\
-0.1 \\
\text { NMC } \\
-0.2 \\
\text { NMC } \\
\text { NMC } \\
\text { NMC }\end{array}$ & $\begin{array}{l}0.77 \\
0.76 \\
0.76 \\
0.75 \\
0.74 \\
0.74 \\
0.73\end{array}$ \\
\hline$C-33$ & 500 & $\begin{array}{r}0 \\
24 \\
69 \\
116 \\
115 \\
209\end{array}$ & $\begin{array}{r}0 \\
24 \\
93 \\
209 \\
324 \\
533\end{array}$ & $\begin{array}{l}14.757 \\
14.756 \text { (d) } \\
14.759 \\
14.755 \\
14.757 \text { (d) } \\
14.759\end{array}$ & $\begin{array}{l}2.931 \\
2.932(\mathrm{~d}) \\
2.929 \\
2.934 \\
2.930(\mathrm{~d}) \\
2.934\end{array}$ & $\begin{array}{l}- \\
\text { NMC } \\
\text { NMC } \\
\text { NMC } \\
\text { NMC } \\
\text { NMC }\end{array}$ & $\begin{array}{l}0.77 \\
0.77 \\
0.76 \\
0.76 \\
0.75 \\
0.76\end{array}$ \\
\hline$C-22$ & 365 & $\begin{array}{r}0 \\
24 \\
72 \\
144 \\
120\end{array}$ & $\begin{array}{r}0 \\
24 \\
96 \\
240 \\
360\end{array}$ & $\begin{array}{l}14.809 \\
14.808 \\
14.810 \\
14.812 \\
14.809\end{array}$ & $\begin{array}{l}2.936 \\
2.932 \\
2.932 \\
2.932 \\
2.925\end{array}$ & $\begin{array}{l}- \\
+0.1 \\
+0.1 \\
+0.1 \\
+0.4\end{array}$ & 0.82 \\
\hline C-11 & 210 & $\begin{array}{r}0 \\
24 \\
72 \\
146 \\
120\end{array}$ & $\begin{array}{r}0 \\
24 \\
96 \\
242 \\
362\end{array}$ & $\begin{array}{l}13.058 \\
13.057 \\
13.058 \\
13.058 \\
13.057\end{array}$ & $\begin{array}{l}2.927 \\
2.924 \\
2.928 \\
2.927 \\
2.917\end{array}$ & $\begin{array}{l}- \\
\text { NMC } \\
\text { NMC } \\
\text { NMC } \\
+0.3\end{array}$ & 0.81 \\
\hline
\end{tabular}

(a) The temperature did not vary more than $\pm 10^{\circ} \mathrm{C}$ at any time during the test.

(b)The precision of the measurements is: weight, $\pm 0.002 \mathrm{~g}$; density, $\pm 0.003 \mathrm{~g} / \mathrm{cc}$; thickness, \pm 0.001 in.

(c) Based on the assumption of no weight change and calculated from the expression: $\% \Delta V=\left[\left(\frac{\rho_{\mathrm{i}}}{\rho_{\mathrm{f}}}\right)-1\right] 100$, where $\rho_{\mathrm{i}}$ and $\rho_{\mathrm{f}}$ are the initial
and final densities, respectively. NMC means no measurable change.

(d) Is the average of two measurements.

There was a difference in the ratio of fuel to aluminum in the two specimens with burnup amounting to $5.9 \times 10^{20}$ fissions per cc. This accounts for the observed difference in the total $\% \Delta \mathrm{V}$ between the specimens and points up the fact that since all the specimens were clad, the $\% \Delta \mathrm{V}$ is dependent upon the geometry and the quantity of aluminum present. Thus, although similar volume increases could have occurred in the fuel core, a specimen containing a larger fraction of aluminum would appear to have a lower total $\% \Delta \mathrm{V}$. The data are thus useful in establishing the swelling temperature but not the absolute magnitude of the change to be expected unless specimens of similar geometry are compared.

\section{B. Metallographic Examination}

Irradiated specimens $\mathrm{W}-12-6$ and $\mathrm{W}-12-\mathrm{TES}$ were examined metallographically at the conclusion of the annealing period. The specimens were mounted with cold-setting plastic and ground to a 600 grit finish on silicon carbide paper dressed with paraffin. They were then rough polished on Nylon cloth impregnated with 6- $\mu$ diamond abrasive and final polished with Microcloth on a plastic lap with Magomet polishing compound. 
The specimens were examined in both the as-polished and etched condition. A swab etch was employed with either a 10 percent $\mathrm{NaOH}$ or a 2 percent HF solution. The sodium hydroxide solution removed deformed metal without etching the $\mathrm{UAl}_{4}$ particles appreciably, whereas the $\mathrm{HF}$ solution had a tendency to attack the $\mathrm{UAl}_{4}$ particles also.

Figures 19 and 20 are typical of the $\mathrm{UAl}_{4}$ particles in specimen W-12-6. After etching the particles stood out in relief. The particles had retained their characteristic diamond shape, and there was no evidence of any cracks within the particles or the aluminum-rich matrix. Some porosity was present in the particles, but this is to be expected at a burnup level

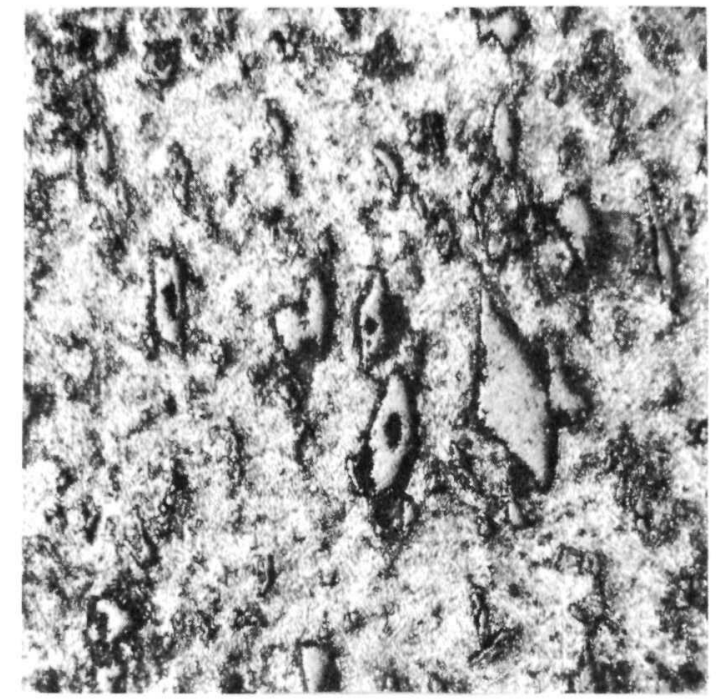

EI-787

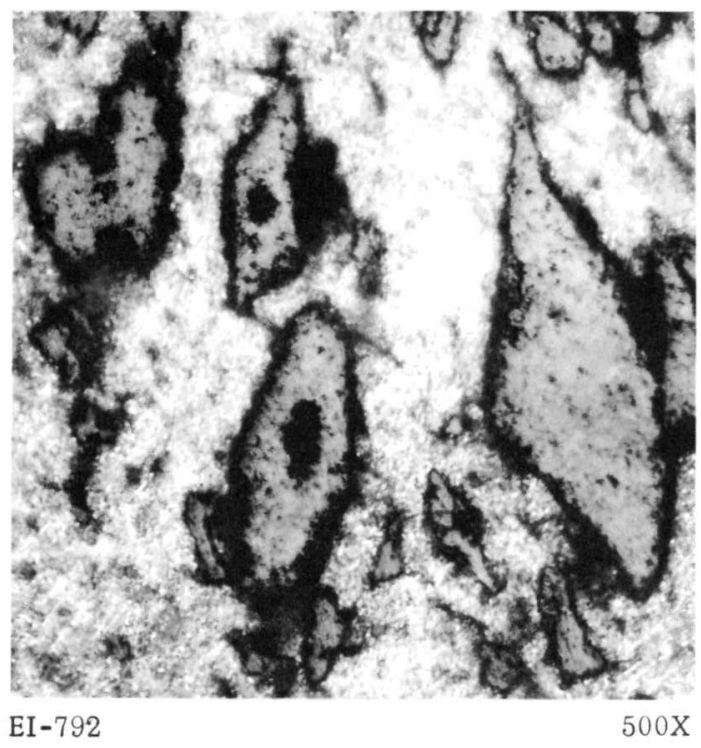

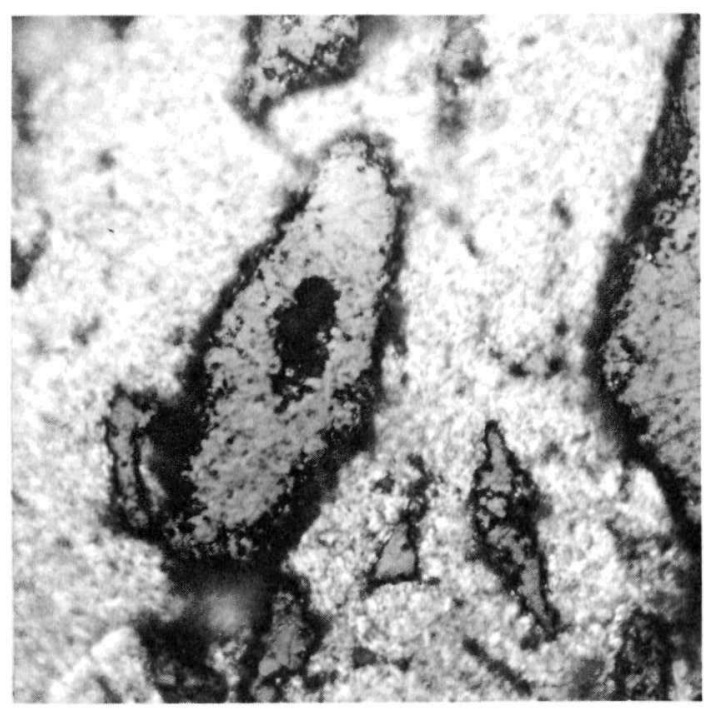

EI-790

$750 \mathrm{X}$

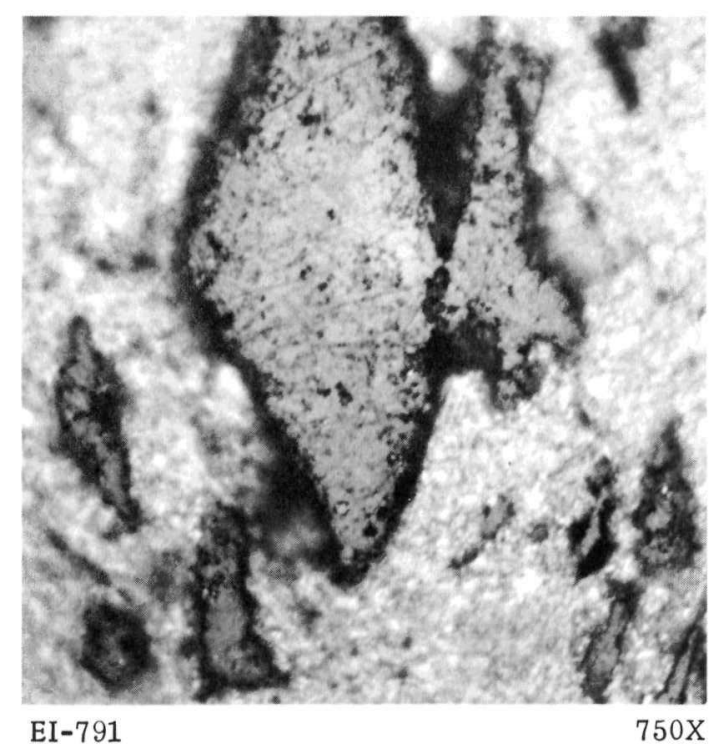

Figure 19. Specimen W-12-6 Showing Particles of $\mathrm{UAl}_{4}$ in Aluminum-rich Matrix. Specimen was annealed for $511 \mathrm{hr}$ at $550^{\circ} \mathrm{C}$. Etched with $\mathrm{NaOH}$. All structures photographed under selective tint. 


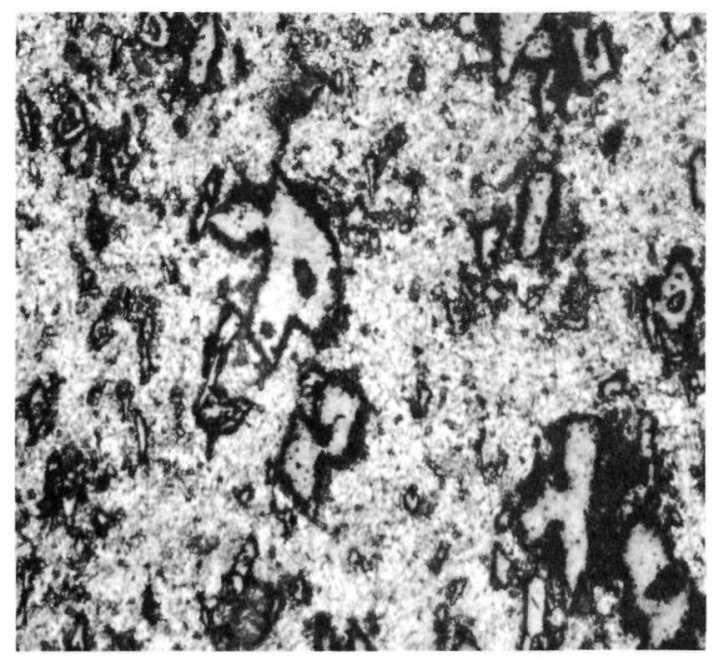

EI-786

$250 \mathrm{X}$

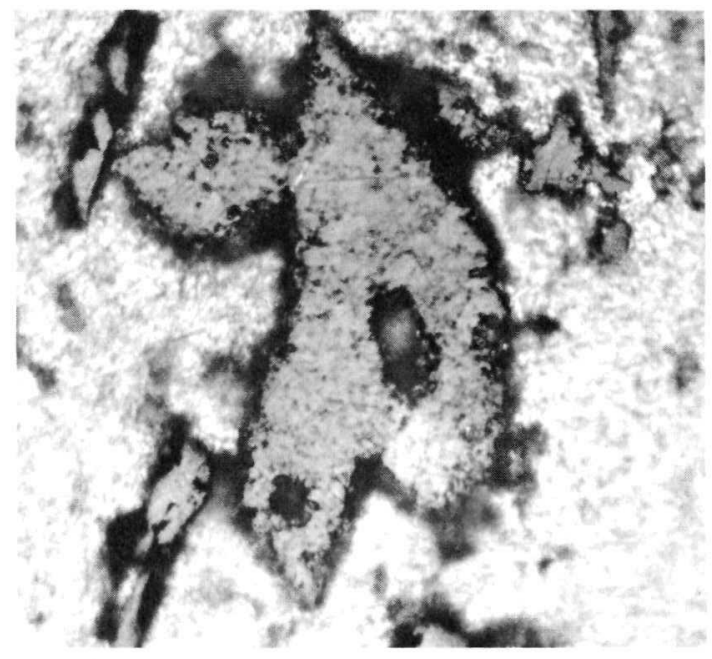

EI-789

$750 \mathrm{X}$

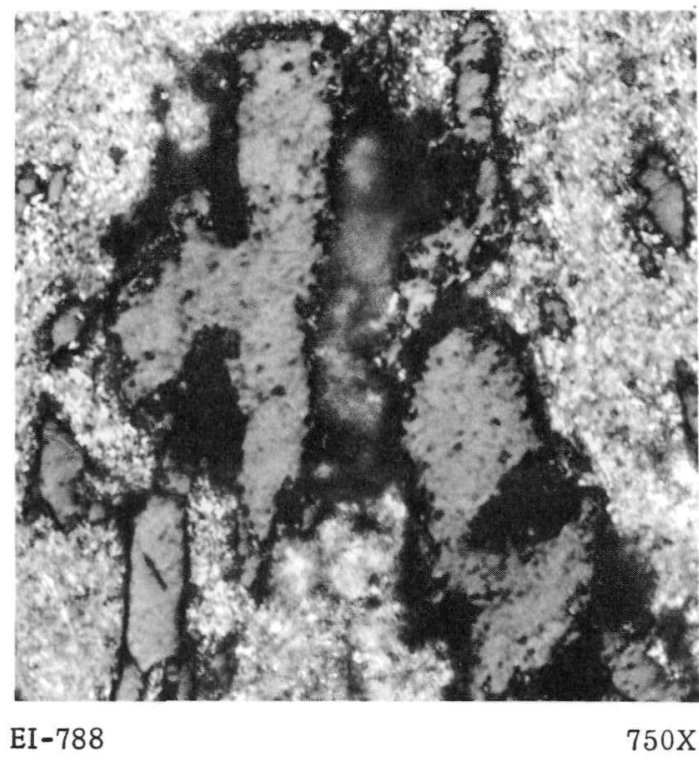

Figure 20. Specimen W-12-6 Showing Particles of UAl 4 in Aluminum-rich Matrix. Specimen was annealed for $511 \mathrm{hr}$ at $550^{\circ} \mathrm{C}$. Etched with $\mathrm{NaOH}$. All structures photographed under selective tint.

of 10 percent of the $\mathrm{U}^{235}$. In general the microstructure revealed that the matrix and the uranium bearing phase were in good condition after irradiation to a burnup of $1.4 \times 10^{20}$ fissions per cc and subsequent annealing at $550^{\circ} \mathrm{C}$ for $511 \mathrm{hr}$.

The microstructure of specimen W-12-TES, which had a burnup about four times that of $\mathrm{W}-12-6$, can be seen in Figure 21 . The $\mathrm{UAl}_{4}$ particles are considerably more porous than those of $\mathrm{W}-12-6$, and many of the particles have lost their original shape. Figures 22 and 23 are macro- and microphotographs showing the void areas in the sample. 


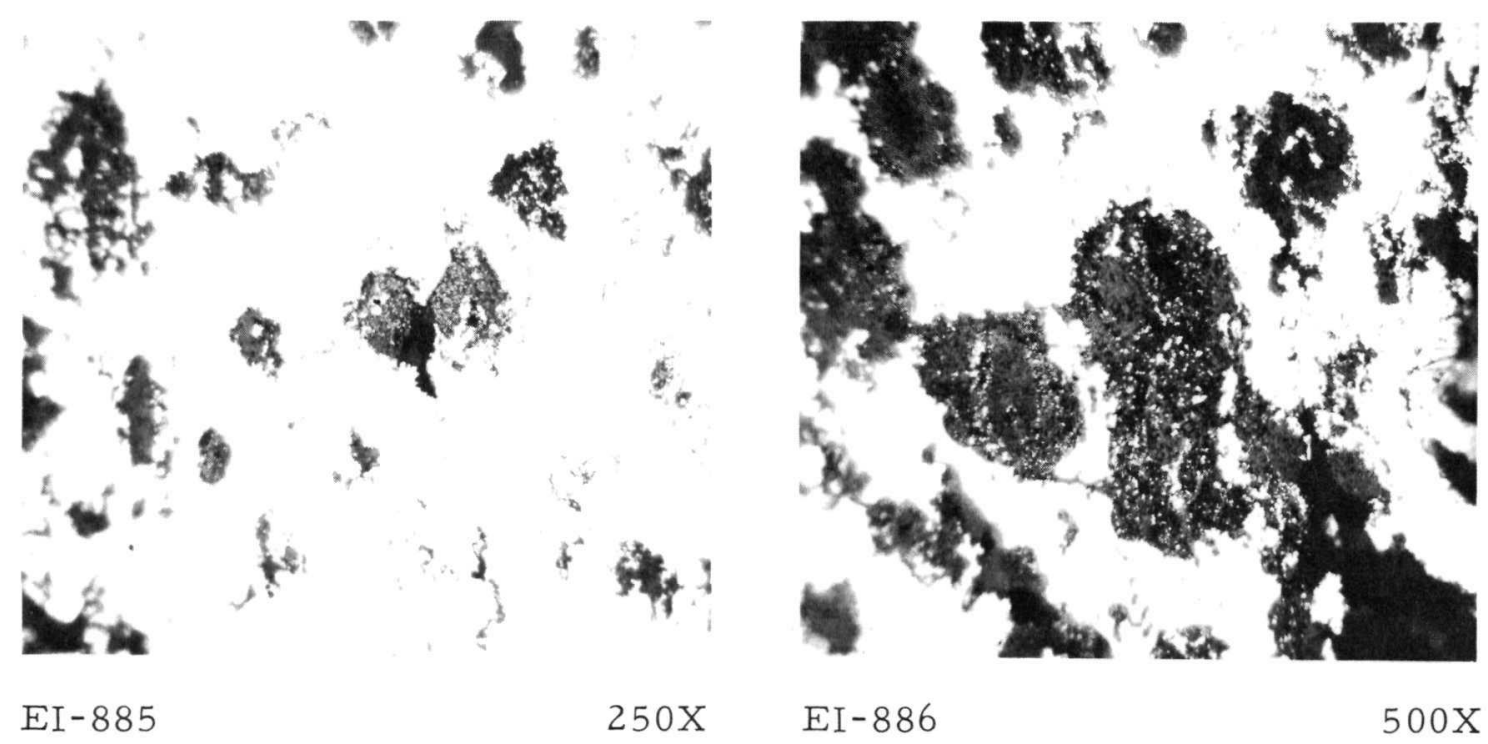

Figure 21. $\mathrm{UAl}_{4}$ Particles in Aluminum Matrix of Specimen W-12-TES. Note porosity present.

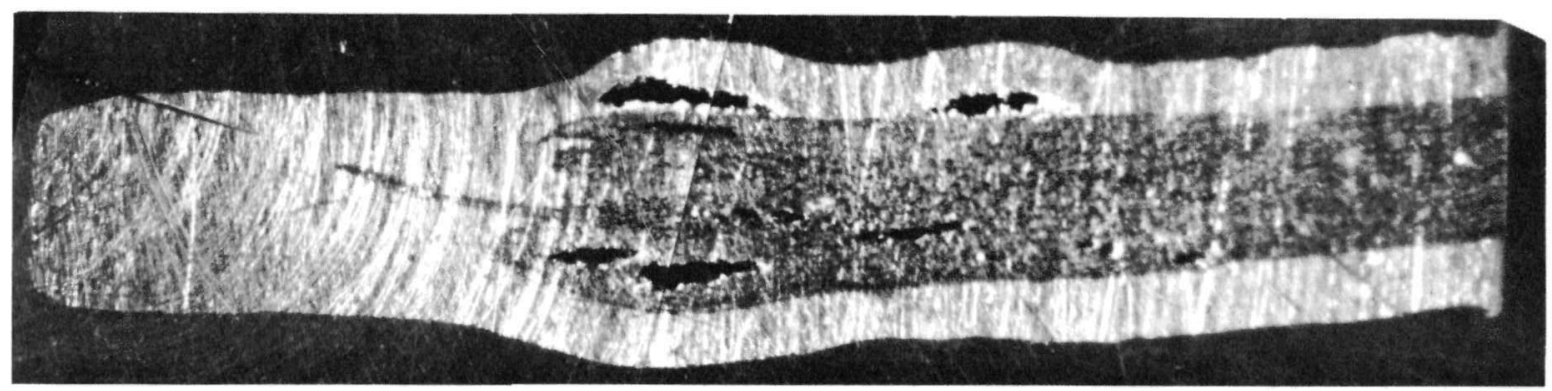

EI-793

Figure 22. Void Formation in Specimen W-12-TES.

Figure 22 also shows blistering in the aluminum cladding itself. The blistering probably did not originate within the cladding. It most probably originated in the fuel core and then extended into the cladding at a point of weakness. It can be seen in the microphotograph that void formation occurred along lines of $\mathrm{UAl}_{4}$ particles.

\section{Discussion}

Based on the results of the annealing studies, the aluminum$17.3 \mathrm{w} / \mathrm{o}$ uranium system exhibited a remarkable resistance to swelling, even considering the fact that the fuel core was clad with 0.027 in. of aluminum. At a burnup of $5.9 \times 10^{20}$ fissions per cc, a temperature fairly close to the melting point of the aluminum was reached before the onset of gross swelling was evident. Similar conditions produced only a small 
uniform volume increase when the burnup was approximately $1.4 \times 10^{20}$ fissions per cc. Similar blistering was observed on an aluminum$17.5 \mathrm{w} / \mathrm{o}$ uranium alloy fuel plate irradiated in a high temperature water loop. (17) The burnup in the blistered area was about $6.6 \times 10^{20} \mathrm{fissions} / \mathrm{cc}$, with a corresponding estimated temperature of $540^{\circ} \mathrm{C}$.

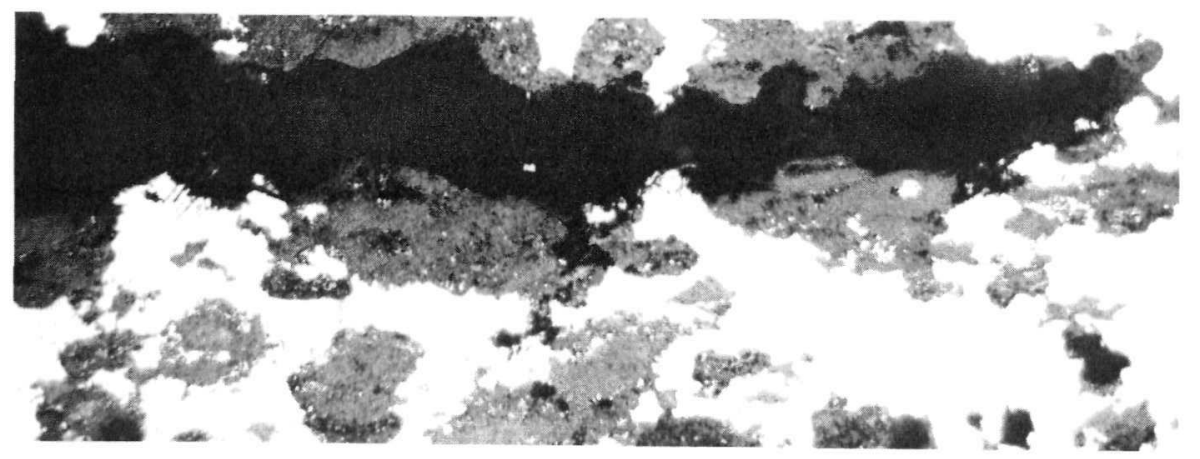

EI-883

$250 x$

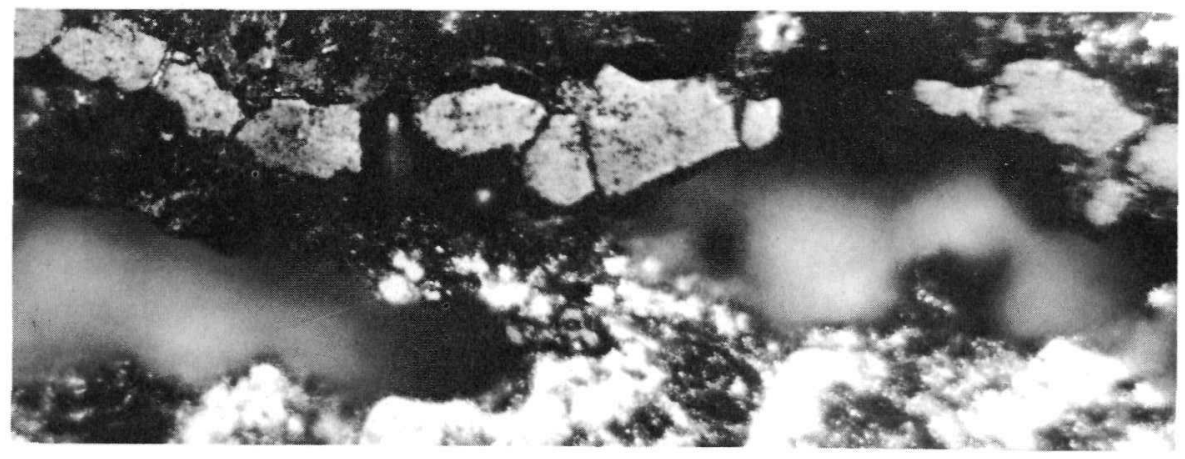

EI-794

$500 x$

Figure 23. Specimen W-12-TES Showing Void Formation along Line of $\mathrm{UAl}_{4}$ Particles. 
An examination of the uranium-aluminum phase diagram, shown in Figure 24, indicates that the aluminum-17.3 w/o uranium alloy is really

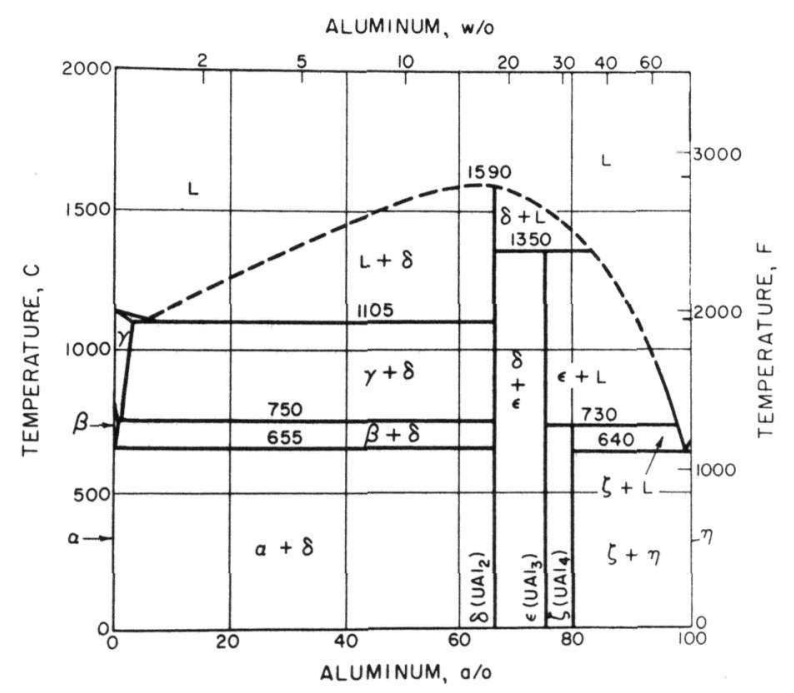

EI- 892

Figure 24. Aluminum-Uranium Phase Diagram. a dispersion of the intermetallic compound $\mathrm{UAl}_{4}$ in an essentially uranium-free aluminum matrix. It is anticipated that any fission gases released from a $\mathrm{UAl}_{4}$ particle would be present at the aluminum- $\mathrm{UAl}_{4}$ particle interface. Once the gas bubbles exceed a critical size, these gases can be expected to follow the perfect gas law. Thus, the pressure exerted by the gases would be directly proportional to the quantity of gas present and the absolute temperature, and inversely proportional to the volume occupied. It is speculated that at elevated temperatures, where the constraint afforded by the aluminum is small, the presence of these gases would produce swelling; the higher the temperature, the less the quantity of gas needed to produce swelling. The volume occupied by the gas would increase until the pressure exerted was balanced by the constraint afforded by the aluminum matrix and cladding. Not only does the physical geometry of the specimens indicate that swelling might well occur as blistering in localized areas, but such blistering has been observed.

A lack of swelling at elevated temperature is taken as an indication of the absence of sizable amounts of gases in the free state surrounding the $\mathrm{UAl}_{4}$ particles. Resistance to swelling would thus seem to be more dependent upon the properties of the intermetallic compound $\mathrm{UAl}_{4}$, and in particular to its ability to retain fission gases, than upon the mechanical properties of the aluminum matrix and cladding or upon the general specimen geometry. Some data have been observed at low burnups which substantiate the ability of $\mathrm{UAl}_{4}$ particles to retain fission gases even at elevated temperatures. (18) In this work there was negligible fission gas release from particles of $\mathrm{UAl}_{4}$ annealed at temperatures below $600^{\circ} \mathrm{C}$. Gas release was usually rapid, however, on initial heating to temperatures above about $650^{\circ} \mathrm{C}$.

$\mathrm{X}$-ray diffraction analyses indicate that the intermetallic compound $\mathrm{UAl}_{4}$ has a body-centered orthorhombic structure with a unit cell of $\mathrm{a}=4.41 \AA, \mathrm{b}=6.27 \AA$, and $\mathrm{c}=13.71 \AA .(19,20)$ Each uranium atom has as its nearest neighbors thirteen aluminum atoms at a minimum interatomic distance of about $3 \AA$. It has also been observed that the measured 
and theoretical densities do not agree.(19) The theoretical density is $6.12 \mathrm{~g} / \mathrm{cc}$, and the measured densities were $5.7 \pm 0.3 \mathrm{~g} / \mathrm{cc}$. This discrepancy is in part explained by assuming a defect structure for the compound $\mathrm{UAl}_{4}$ in which some of the uranium sites are unoccupied. The potential ability of these sites to trap fission products and, in particular, fission product gases may in part explain the excellent stability of $\mathrm{UAl}_{4}$ at high burnup and temperatures. It is noteworthy that if the resistance to swelling of the aluminum-17.3 w/o uranium system is due to the properties of the $\mathrm{UAl}_{4}$ intermetallic compound, then all the compositions with uranium concentrations of up to $20 \mathrm{a} / \mathrm{o}$ should also exhibit this resistance.

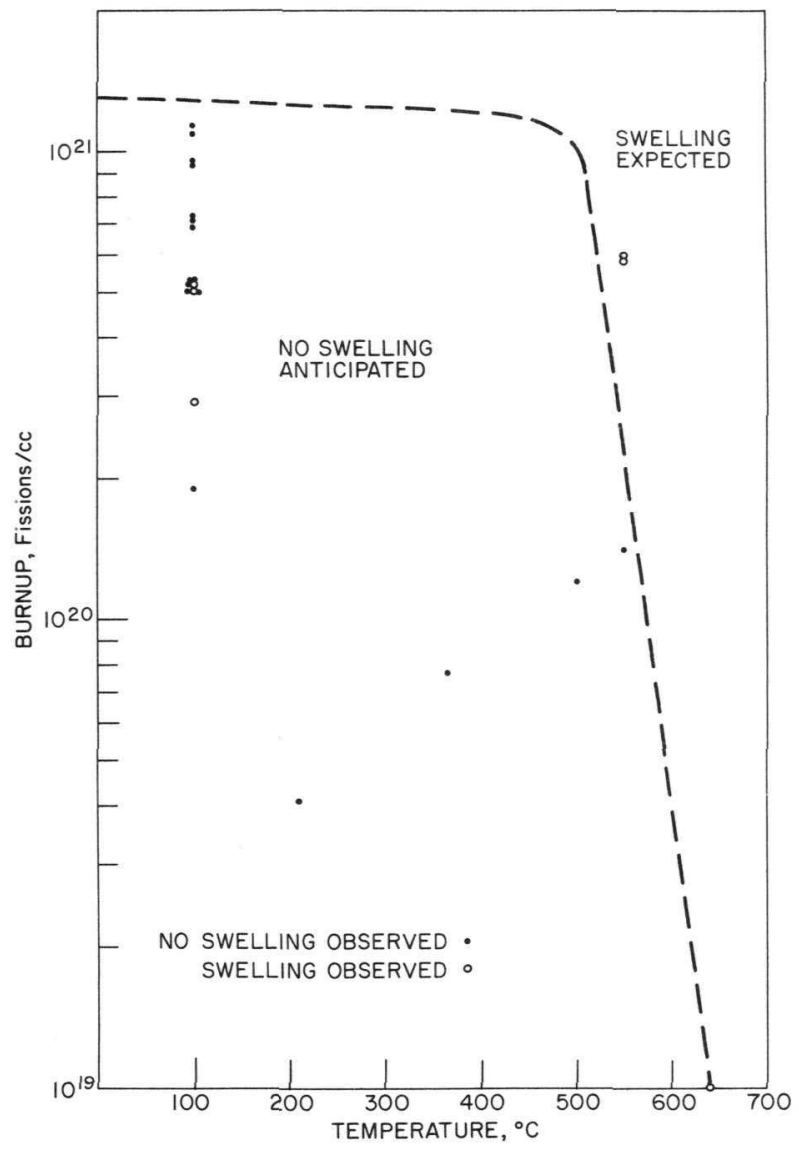

$106-7280$

Figure 25. Swelling in Aluminum-17 to $20 \mathrm{w} / 0$ Uranium Alloy Specimens as a Function of Burnup and Temperature.
Recent data on platelets of aluminum-18 to $23 \mathrm{w} / \mathrm{o}$ uranium fuel, clad with 0.015 in. of aluminum and ir radiated at approximately $100^{\circ} \mathrm{C}$, indicate good dimensional stability. (21) Average volume increases of about 2 to 4 percent were noted for burnups ranging up to $11.3 \times 10^{20}$ fissions per cc. It is concluded from these results and those discussed above that swelling in the aluminum-17.3 w/o uranium system should be more dependent upon temperature than upon burnup. Figure 25 is a plot of burnup versus temperature for the aluminumuranium system of about 17 to $20 \mathrm{w} / \mathrm{o}$ uranium. The data at $100^{\circ} \mathrm{C}$ were obtained from Ref. 21, which described tests of samples having 0.020-in. -thick fuel cores clad with 0.015 in. of various aluminum alloy claddings. The upper temperature limit was assumed. It was based on the observed data of Reynolds(18) which indicated sizable quantities of fission gas release even at low burnup when particles of $\mathrm{UAl}_{4}$ were annealed at about $640^{\circ} \mathrm{C}$. The intervening data are the results of the present annealing studies on 0.050in.-thick fuel cores clad with approximately 0.030 in. of $\mathrm{X}-8001$ aluminum alloy.

The plot is separated into two regions. In the region below the line combinations of burnup and temperature are postulated which are stable, whereas those above the line are combinations of burnup and 
temperature which will produce swelling. Swelling, for purposes of the plot, is defined as severe localized blistering or general volume increases exceeding 10 percent per atom percent burnup. The line is dotted to emphasize the fact that the data points are not extensive; thus, the curve must be considered tentative until verified by additional data at elevated temperature and burnup.

The form of swelling taken by the aluminum-17.3 w/o uranium specimens used in the annealing studies was severe localized blistering. It is believed that the blistering originated in a stringered area when fission product gases were released from the $\mathrm{UAl}_{4}$ particles and readily joined with other gases from adjacent particles because the aluminum did not provide sufficient mechanical strength at the temperatures involved to restrain them. Two such areas can be seen in Figure 23.

\section{General Comparison between the Alloy and Dispersion Systems}

The alloy and dispersion systems cannot be compared directly on the basis of the data developed during the present annealing study because of the varying amounts of restraint afforded by the differing geometries. Although at temperatures above $500^{\circ} \mathrm{C}$, at which the strength afforded by the aluminum is not great, direct comparisons may yield reasonable approximations of the relative capabilities of the two systems.

For burnups up to about $1 \times 10^{20}$ fissions per $\mathrm{cc}$ and temperatures ranging up to $500^{\circ} \mathrm{C}$, the $39 \mathrm{w} / \mathrm{o} \mathrm{U}_{3} \mathrm{O}_{8}$-aluminum dispersion system had slightly larger volume increases than the aluminum-17.3 w/o uranium alloy system. This difference may be due to the fact that the alloy specimens were more highly restrained. Actually, if it were not for the reaction between the aluminum and the $\mathrm{U}_{3} \mathrm{O}_{8}$, the dispersion specimens would have exhibited better resistance than the alloy. Thus, although the dispersion system may be slightly more resistant to fission gas swelling in this range, the volume increase accompanying the aluminum $-\mathrm{U}_{3} \mathrm{O}_{8}$ reaction makes it slightly less resistant to overall swelling than the alloy.

The large difference in burnup between specimens annealed at $550^{\circ} \mathrm{C}$ does not allow a comparison to be drawn between the two systems.

It has been noted that at temperatures above $210^{\circ} \mathrm{C}$ the aluminum matrix and $\mathrm{U}_{3} \mathrm{O}_{8}$ react with the eventual formation of $\mathrm{UAl}_{4}$. Measurable volume increases accompany this reaction, and data indicate that at completion a volume increase of about $4 \%$ can be expected.(15) Aluminum systems with up to $20 \mathrm{a} / \mathrm{o}$ uranium exist as the intermetallic compound $\mathrm{UAl}_{4}$ in an essentially uranium-free aluminum matrix. Since the uranium in the $\mathrm{U}_{3} \mathrm{O}_{8}$ will eventually revert to $\mathrm{UAl}_{4}$, the alloy system would seem to be basically more resistant to volume increases, for it does away with the volume increase accompanying the aluminum $-\mathrm{U}_{3} \mathrm{O}_{8}$ reaction. 


\section{CONCLUSIONS}

1. Specimens containing $39 \mathrm{w} / 0 \mathrm{U}_{3} \mathrm{O}_{8}$ dispersed in aluminum were in excellent condition after being irradiated to burnups ranging up to $1 \times 10^{20}$ fissions per $\mathrm{cc}$ at temperatures between 55 and $90^{\circ} \mathrm{C}$.

2. Based on the annealing studies, $39 \mathrm{w} / 0 \mathrm{U}_{3} \mathrm{O}_{8}$-aluminum dispersions are resistant to swelling for burnup and temperature levels up to at least $1 \times 10^{20}$ fissions per cc and $550^{\circ} \mathrm{C}$, respectively.

3. $\mathrm{U}_{3} \mathrm{O}_{8}$ reacts with aluminum at temperatures as $10 \mathrm{w}$ as $210^{\circ} \mathrm{C}$ with the formation of $\mathrm{UO}_{2}, \mathrm{Al}_{2} \mathrm{O}_{3}$, and $\mathrm{U}-\mathrm{Al}$ intermetallic compounds. Temperature, time, and particle size are variables which affect the rate of the reaction.

4. Volume increases accompany the $\mathrm{U}_{3} \mathrm{O}_{8}$-aluminum reaction. After approximately $500 \mathrm{hr}$ the volume increases amounted to $1 \%$ at $500^{\circ} \mathrm{C}$ and to $3 \%$ at $550^{\circ} \mathrm{C}$. After approximately $360 \mathrm{hr}$ the volume increases amounted to about $0.5 \%$ at $210^{\circ} \mathrm{C}$ and $365^{\circ} \mathrm{C}$.

5. The dispersion specimens and, in particular, the $\mathrm{U}_{3} \mathrm{O}_{8}$ particles sintered during irradiation at temperatures from 55 to $90^{\circ} \mathrm{C}$ in an effective the rmal neutron flux of between 1 and $3 \times 10^{13} \mathrm{nv}$.

6. Based on the annealing studies, $17.3 \mathrm{w} / \mathrm{o}$ uranium-aluminum specimens having burnups up to at least $1.4 \times 10^{20}$ fissions per cc are resistant to swelling at temperatures as high as $550^{\circ} \mathrm{C}$.

7. Based on the annealing studies, $17.3 \mathrm{w} / \mathrm{o}$ uranium-aluminum specimens with burnups equal to $5.9 \times 10^{20}$ fissions per cc will swell rapidly at $550^{\circ} \mathrm{C}$. The swelling occurs as severe localized blistering.

\section{ACKNOW LEDGEMENTS}

The author wishes to acknowledge the efforts of the designated individuals who contributed to the following phases of the study:

\begin{tabular}{|c|c|}
\hline D. E. Walker & Specimen Fabrication \\
\hline J.H. Kittel & Capsule Irradiations \\
\hline F.J.Tebo & $\begin{array}{l}\text { Electrical Geometrical } \\
\text { Analogue Study }\end{array}$ \\
\hline A. Horak & Flux Monitor Analyses \\
\hline W. C. Kettman & Data Collection \\
\hline R. P. Larsen & Burnup Analyses \\
\hline R. Carlander & Metallography \\
\hline [. W. Knott & X-ray Diffraction \\
\hline
\end{tabular}




\section{REFERENCES}

1. J. H. Handwerk, R. A. Noland, and D. E. Walker, Method of Fabrication of Fuel Elements Using Metal Powder and $\mathrm{U}_{3} \mathrm{O}_{8}$, U. S. Patent No. 2,805,473 (Sept 1957).

2. R. A. Noland, D. E. Walker, and L. C. Hymes, ASTM Special Technical Publication No. 276, Fabrication of $\mathrm{U}_{3} \mathrm{O}_{8}$-Aluminum Dispersion Fuel Elements by Extrusion, p. 336, American Society for Testing Materials (1960).

3. D. H. Lennox and C. N. Kelber, Summary Report on Hazards of Argonaut Reactor, ANL-5647 (1956).

4. J. H. Kittel, C. C. Crothers, and R. Carlander, Irradiation of an Aluminum-Uranium Alloy Fuel Plate under Local Boiling Conditions, ANL-6607 (to be published).

5. R. A. Noland, D. E. Walker, M. Martin, and S. Matras, Manufacture of Fuel Plates and Fuel Assemblies for the Argonne Low Power Reactor, ANL-5965 (to be published).

6. R. A. Noland, Manufacture of Fuel Plates and Fuel Assemblies for the Argonne Low Power Reactor, TID-7559, I 233-244 (1958), Paper presented at Fuel Element Conference at Gatlinburg, Tennessee, May 14-16, 1958.

7. R. L. Salley and W. R. Burt, Jr., Casting and Fabrication of Core Materials for Argonne Low Power Reactor Fuel Elements, ANL-5950 (1959).

8. D. E. Walker, R. A. Noland, F. D. McCuaig, and C. C. Stone, BORAX-IV Reactor: Manufacture of Fuel and Blanket Elements, ANL-5721 (1958).

9. E. W. Hoyt and D. L. Zimmerman, Radiation Effects in Borides, Part II - Fission Sintering of Boride Powders, GEAP-3743 (1962).

10. R. A. Ewing and D. N. Sunderman, Effects of Radiation upon Hafnium Diboride, BMI-1521 (1961).

11. W. K. Barney and B. D. Wemple, Metallography of $\mathrm{UO}_{2}$ Containing Fuel Elements, KAPL-1836 (1958).

12. E. A. Aitken, Sintering Characteristics in a Radiation Environment, Paper presented at the ASTM Symposium on Radiation Effects in Refractory Fuel Compounds, Atlantic City, New Jersey, June 1961.

13. J. E. Burke, Role of Grain Boundaries in Sintering, J. Am. Cer. Soc., $\underline{40}(3), 80-85$ (1957).

14. A. E. Eiss, Reactivity of Certain Uranium Oxides with Aluminum, SCNC-257 (1958). 
15. R. C. Waugh and R. J. Beaver, Recent Developments in the Powder Metallurgy Application of Uranium Oxides to Aluminum Research Reactor Fuel Elements, CF-57-9-60 (1957).

16. R. C. Waugh, The Reaction and Growth of Uranium Dioxide-Aluminum Fuel Plates and Compacts, ORNL-2701 (1959).

17. A. P. Gavin and C. C. Crothers, Irradiation of an Aluminum Alloyclad, Aluminum-Uranium Alloy-fueled Plate, ANL-6180 (1960).

18. M. B. Reynolds, Fission Gas Behavior in the Uranium-Aluminum System, Nuclear Sci. and Eng., 3, 428-434 (1958).

19. B. S. Borie, Jr., Crystal Structure of $\mathrm{UAl}_{4}$, J. of Metals, 3, 800 (1951).

20. A. H. Snell and E. O. Wollan, Quarterly Progress Report for Period Ending March 15, 1950, ORNL-693 (1950).

21. G. W. Gibson and O. I. Shupe, Annual Progress Report on Fuel Element Development for FY 1961, IDO-16727 (1962). 


\section{APPENDIX \\ Method of Correcting Specimen Weights and \\ Volumes for Salt Pickup}

From Table VI the measured weight and density of specimen ED-6 were $6.018 \mathrm{~g}$ and $2.956 \mathrm{~g} / \mathrm{cc}$, respectively, after annealing for $51 \mathrm{l} \mathrm{hr}$ at $550^{\circ} \mathrm{C}$. The original weight and density were $4.815 \mathrm{~g}$ and $3.383 \mathrm{~g} / \mathrm{cc}$.

The original specimen weight minus the final specimen weight gives the weight of the salt picked up:

$6.018-4.815=1.203 \mathrm{~g}$.

The volume occupied by the salt is given by

$\underset{\text { salt }}{\operatorname{volume}}=\frac{\text { weight of salt }}{\text { density of salt }}=\frac{1.203 \mathrm{~g}}{2.18 \mathrm{~g} / \mathrm{cc}}=0.552 \mathrm{cc}$

From the data in Table VI the volume occupied by the specimen plus the salt is

$$
\text { volume of specimen }+ \text { salt }=\frac{6.018}{2.956}=2.036 \mathrm{cc} \text {. }
$$

The corrected volume of the specimen is thus

$2.036-0.552=1.484 \mathrm{cc}$.

The corrected density is given by

$$
\frac{4.815}{1.484}=3.244 \mathrm{~g} / \mathrm{cc}
$$

Thus, the $\% \Delta \mathrm{V}$ is given by $\left[\frac{\rho_{i}}{\rho_{f}}-1\right] 100$,

which for this case is

$$
\left[\frac{3.383}{3.244}-1\right] 100=4.2 \%
$$

as given in Table VI. 